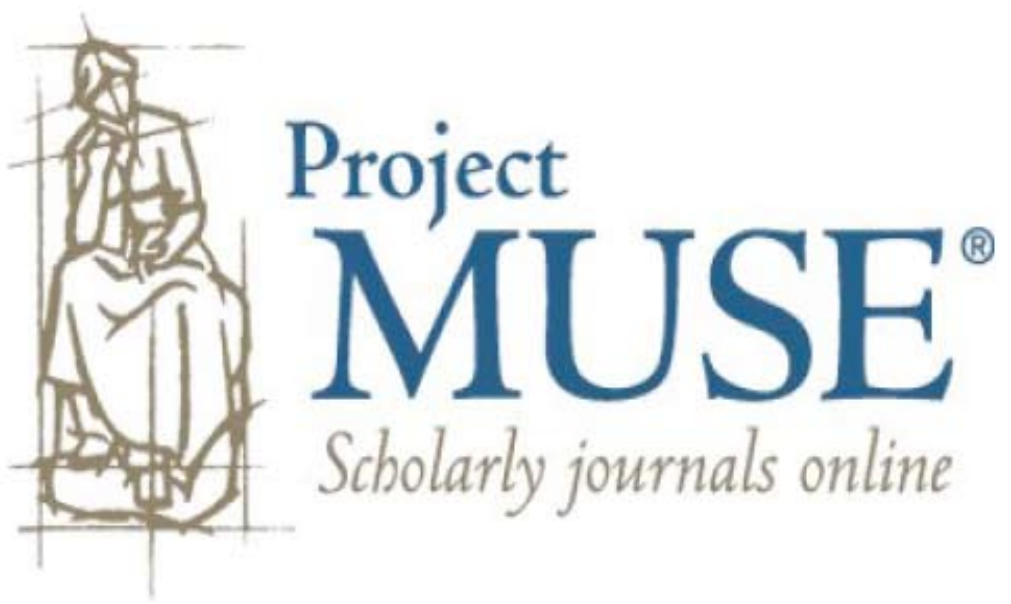




\section{LANGUAGE CHANGE ACROSS THE LIFESPAN: /r/ IN MONTREAL FRENCH}

\section{GiLlian SAnKofF}

\section{University of Pennsylvania}

\author{
HÉLÈne BLONDEAU
}

University of Florida

We address the articulation between language change in the historical sense and language change as experienced by individual speakers through a trend and panel study of the change from apical to dorsal /r/ in Montreal French. The community as a whole rapidly advanced its use of dorsal $[R]$. Most individual speakers followed across time were stable after the critical period, with phonological patterns set by the end of adolescence. A sizeable minority, however, made substantial changes. The window of opportunity for linguistic modification in later life may be expanded with rapid change in progress when linguistic variables take on social significance.*

1. Introduction. Reintegrating synchronic and diachronic linguistics by studying language change in progress, Weinreich, Labov, and Herzog (1968) demonstrated that change necessarily involves diffusion. They showed that language change implies variation (though not the reverse), and that as an innovation diffuses through the speech community, the social structure of that community conditions its path. Subsequent research has not, however, directly addressed the question of the articulation between language change in the historical sense and language change as experienced by individual speakers. We take this as our central concern in analyzing a phonological change in Montreal French - the community shift in the pronunciation of $/ \mathrm{r} /$ - on the basis of data collected in 1971 and 1984. We address three major goals in our exploration of the problem. First, we look at the two major types of longitudinal research: trend and panel studies, and evaluate the relative contribution of each. Second, we assess the extent to which predictions based on an apparent-time interpretation of our 1971 age distribution represent a change in progress that has continued, as measured against realtime longitudinal data. Third, we reconsider the role of the critical period in language acquisition as it relates to language change.

The analysis of the relation between vocalized and consonantal / $r$ in New York City was a crucial early study (Labov 1966). Labov cites several earlier observers whose descriptions of New York City held it to be chaotic. According to Hubbell, for example, 'The pronunciation of a very large number of New Yorkers exhibits a pattern in these words [those containing post-vocalic / $\mathrm{r} /$ ] that might most accurately be described as the complete absence of any pattern' (Hubbell 1950:48, cited in Labov 1966:36). Labov replaced this idea of New York City speech as chaos by explaining variation in $/ \mathrm{r} /$ (and

\footnotetext{
* We thank the National Science Foundation for funding this research (Language Change Across the Lifespan, Grant BCS-0132463 to Gillian Sankoff). This joint research was begun when Hélène Blondeau held a postdoctoral fellowship from the Fonds pour la Formation de Chercheurs et l'Aide à la Recherche, Gouvernement du Québec, at the University of Pennsylvania in 1999-2001. We gratefully acknowledge the invaluable contributions of David Sankoff and Henrietta Cedergren in codesigning and implementing (along with the first author) the original Montreal study in 1971; of Pierrette Thibault and Diane Vincent in carrying out the 1984 followup study; and of Diane Vincent, Marty Laforest, and Guylaine Martel in undertaking the 1995 followup. We are especially grateful to Pierrette Thibault for her help in making materials of many kinds available for our present research, often at short notice, and thank her and Bill Labov for discussion of theoretical and methodological issues, as well as questions of substance. For their assistance in coding and verification of the data, we thank Anne Charity, Alice Goffman, Daniel Alejandro Gonzales, Sarah Moretti, and Sergio Romero. Michael Friesner and Damien Hall not only helped with final coding and verification, but also made many useful suggestions on an earlier version of the manuscript. We thank Malcah Yaeger-Dror for checking data on some of the speakers whose vowels she analyzed in the 1971 and 1984 corpora and for helpful comments on the manuscript. We also thank Miriam Meyerhoff, Kirk Hazen, Brian Joseph, and two anonymous referees for many constructive comments.
} 
the four other phonological variables he examined) in terms of ongoing language change, structured according to the social stratification of the speech community.

The current article is also a study of $/ \mathrm{r} /$. It examines a change in progress in the pronunciation of $/ \mathrm{r} /$ in Montreal French, during a period when the older, apical [r] pronunciation was 'in rapid regression' (Santerre 1978:117) in favor of 'posterior' or dorsal $[\mathrm{R}] .{ }^{1}$ The rapidity of this change during the 1960s and 1970s contrasts markedly with the slow pace of diminishing (r) vocalization in New York (Labov 1994). Before proceeding to the Montreal case, it is important to explain how the three specific goals of our article fit into the larger project of understanding the relationship between historical change and individual speakers.

Though most sociolinguistic studies over the past forty years have necessarily been synchronic, making use of the present to explain the past (Labov 1975), there are now a number of longitudinal research projects that have produced valuable results. These projects, designed mainly as TREND STUDIES, in which communities that had been studied a decade or more previously were resampled, include Brink \& Lund 1979, Cedergren 1988, Trudgill 1988, Thibault \& Daveluy 1989, Ashby 2001, Blake \& Josey 2003, and Josey 2004. A second type of longitudinal study is the PANEL STUDY, in which the same individuals are followed across time. In general, the considerable logistical problems and consequent expense involved in such research have precluded large-scale panel followups; several researchers, however, have carried out such studies, usually with rather smaller samples (e.g. Baugh 1995, Cukor-Avila 2002, Hernandez-Campoy 2003, Nahkola \& Saanilahti 2004). Some studies have included both trend and panel components (Paunonen 1996, Blondeau 2001, Naro \& Scherre 2002, de Paiva \& Duarte 2003, Zilles 2005). Trend studies clearly constitute the best use of resources if the object is to track language change in progress. However, the combination of trend and panel research is essential for the interpretation of change, especially as regards the relationship of change to individual grammars (see also Blondeau 2006 on this point). Both types of longitudinal sociolinguistic research are crucial in building more informed models of the role of individual speakers, over their lifetimes, in language change.

Stability of the grammars of individuals after initial language acquisition is the premise that underlies the concept of APPARENT TIME, introduced by Labov in his early studies of Martha's Vineyard (1963) and New York City (1966) as part of a demonstration of the integration of synchronic and diachronic analysis in linguistics. In both cases, he used observations made at earlier periods to verify that, by and large, the speech of older people tends to reflect the state of the language when they acquired it. Table 1 represents Labov's review of the logical possibilities for interpretation of two different patterns that might be observed in a synchronic study. When use of a particular variant is plotted against speaker age, we may see either a flat pattern or a regular increasing or decreasing slope with age. ${ }^{2}$

If a synchronic study shows no age differentiation (the 'flat' pattern), we can infer either that no change is occurring-both individual speakers and the community as a whole are stable (interpretation \#1), or that all the speakers in the community are

\footnotetext{
${ }^{1}$ We use [r] as a convenient symbol to represent the apical flap. Tousignant (1987a,c) discusses various pronunciations of dorsal /r/, including velar fricative $([\gamma]$ or $[\mathrm{x}]$ ), uvular fricative $[\mathrm{G}]$, and uvular trill $[\mathrm{R}]$, mentioning also the environmentally conditioned variability in degree of voicing. We use the symbol [R] to include all dorsal variants.

${ }^{2}$ Other age-related patterns might of course be possible, but would not be of interest in making temporal inferences.
} 


\begin{tabular}{|c|c|c|c|}
\hline SYNCHRONIC PATTERN & INTERPRETATION & INDIVIDUAL & COMMUNITY \\
\hline flat & 1. Stability & stability & stability \\
\hline regular slope with age & 2. Age grading & change & stability \\
\hline regular slope with age & $\begin{array}{l}\text { 3. Generational change } \\
(=\text { apparent-time interpretation) }\end{array}$ & stability & change \\
\hline flat & 4. Communal change & change & change \\
\hline
\end{tabular}

TABLE 1. Patterns of change in the individual and the community (adapted from Labov 1994:83).

changing together at the same rate-both older and younger speakers are at the same stage in a change affecting them equally (interpretation \#4). By contrast, a regular slope with age may mean that generation after generation, individuals change as they get older, yet the community remains stable over time. According to this interpretation (\#2, AGE GRADING), as each cohort of speakers ages, it steadily increases its use of one variant of the variable. Labov (1964) provides an example of this in analyzing stages that children go through in the acquisition of standard English. Alternately, individuals may retain their childhood patterns, with each age cohort of speakers registering an increasing use of the variant upon entering the community. This generational change corresponds to the classic apparent-time interpretation (\#3) of change in progress. ${ }^{3}$

Judicious use of the apparent-time interpretation of age-graded variability has been a hallmark of sociolinguistic research for the past thirty years. However, given the largely synchronic nature of most studies, it has not been possible to verify models of the locus of change with respect to individual speakers. Sankoff 2005, 2006 suggested a distinction between two separate patterns involving speaker change in a situation where we observe a regular slope correlated with speaker age. In the first or classic case, we can use the term age grading in the traditional sense, assuming a generational pattern that is cyclic or repeats as a function of cultural dictates of what is appropriate to speakers of a given age. But another possibility is 'lifespan change', in which 'individual speakers change over their lifespans in the direction of a change in progress in the rest of the community' (Sankoff 2005:1011). Such a pattern would be historical (rather than cyclic) in character. Labov's (1994) discussion of Cedergren's (1988) restudy of (ch) variation in Panamanian Spanish demonstrates that the age distribution includes both an apparent-time and an age-grading component. It leaves open, however, the question of whether the age grading observable from the restudy is a matter of ageappropriate frequencies that would be cyclical in character, or a change in which individuals over their lifespans are swept along with historical language change in the wider community. The model put forward in Table 2 represents the addition of a lifespanchange component distinct from the traditional concept of age grading in that it does not necessarily imply cylicity. We explore the extent to which such a model is justified empirically in the present case.

Last, we are interested in how the change is experienced by individual speakers past puberty, and in the relationship of our study to the critical period. The current literature modeling language change tends to locate it within the scope of first language acquisition (e.g. Lightfoot 1999), although this is more a tacit assumption in the field than a much-researched topic. In a recent treatment of the relationship between brain develop-

\footnotetext{
${ }^{3}$ Figure 1, which is discussed in further detail below, serves as an example of these two possible interpretations. According to the apparent-time interpretation, the curve represents a change in progress in which [R] is replacing $[\mathrm{r}]$ in the community; according to an age-grading interpretation, young speakers currently using [R] would progressively replace it with [r] as they age.
} 
SYNCHRONIC PATTERN flat

regular slope with age regular slope with age regular slope with age

flat
1. Stability
2a. Age grading
2b. Lifespan change
3. Generational change
(= apparent-time interpretation)
4. Communal change

$\begin{array}{cc}\text { INDIVIDUAL } & \text { COMMUNITY } \\ \text { stability } & \text { stability } \\ \text { change } & \text { stability } \\ \text { change } & \text { change } \\ \text { stability } & \text { change } \\ \text { change } & \text { change }\end{array}$

INDIVIDUAL

change

TABLE 2. Addition of a pattern reflecting lifespan change that accompanies change at the level of the community.

ment and individual phonological systems, Anderson and Lightfoot argue that puberty poses an important limit:

In the early years of life, the brain develops vast numbers of new synapses, peaking at about 2 years of age. Over the next several years, neurons die and synapses wither, resulting in a specifically limited organization. Neuron death levels out at around age 7, while overall synaptic organization is determined by around the age of puberty. If we assume that the role of experience is to shape and mold this specific organization, then whatever is in place by puberty is what we are 'stuck with'. (2002:209; scare quotes in the original)

Analyzing speakers age fifteen and above across the thirteen-year interval between 1971 and 1984, we verify how labile individuals are in later life, and how our results relate to what is known about the critical period.

2. /r/ IN MONTREAL FRENCH. As a prelude to his study of /r/ variation in contemporary German, Wiese (2001) surveys rhotics crosslinguistically. He notes that rhotics may have at least three places of articulation ('dental/alveolar; postalveolar/retroflex; and uvular'), and that 'manner of articulation . . . is at least as variable, [including] trills, fricatives, approximants, taps/flaps, and vowels' (Wiese 2001:11). As in numerous other languages, Québécois French includes many of these variants. Morin points out, with justice, that although the articulation of /r/ was variable in Paris in the seventeenth century, the first French colonists to arrive in New France would probably have been users of apical [r] (Morin 2002:51). At the end of the nineteenth century, apical [r] was still the norm in the Province of Quebec. In 1901, Laval University Professor Adjutor Rivard opined that the dorsal articulation was a "vice de prononciation [qui] vient quelquefois d'une certaine paresse de la langue, plus souvent de l'affectation, où encore d'une habitude contractée dès l'enfance'4 (Morin 2002:51, citing Rivard 1928 [1901]). As of the mid-twentieth century, however, there was a clear geographical split. Vinay's survey of 1947-1950 confirmed that Western Quebec, including Montreal, was characterized by the traditional apical [r], tapped or trilled (Vinay 1950). The observations of Father Laurent Tremblay in 1941 confirmed the normative acceptability of this variant at the time (Verreault \& Lavoie 1999); Charbonneau (1955) also described [r] as the Montreal norm. A dorsal [R] (velar fricative or uvular trill) was typical of the eastern part of the province, a zone comprising all points east of Trois Rivières including Quebec City (Vinay 1950). ${ }^{5}$

\footnotetext{
${ }^{4}$ Dorsal articulation was a 'defect of pronunciation which may stem from a certain linguistic laziness, more often from affectation, or else from a habit contracted from childhood' (Gillian Sankoff translation).

${ }^{5}$ There is no generally agreed upon date as to when Eastern Quebec may have adopted dorsal [R]. Noting /r/ variability over several centuries on both sides of the Atlantic, Morin proposes a possible scenario for the eventual establishment of dorsal $[R]$ as the norm in Quebec City and elsewhere in Eastern Quebec. On this view, apical [r], brought by colonists in the 1600s, would have been established earliest, but dorsal [R] might have been dominant among colonists settling in the capital (Quebec City) during the second century of colonization (between 1700 and 1760, when French administration ended). Rivard's 1928 [1901] remarks about dorsal [R] being the result of laziness or childhood habits may attest to its already having been quite well established in Eastern Quebec by that time. Morin (2002:51) notes that in the Atlas linguistique de l'est
} 
Canonical /r/ as [r] or [R], then, depends largely on the region. Though in the course of change in Montreal, many speakers vary between the two, we observe only minimal phonetic conditioning between these variants for the variable speakers (Sankoff \& Blondeau 2007). But a number of other variants occur in rapid speech. These are generally conditioned according to principles detailed in the careful phonetic studies of Tousignant (1987a,b,c). Briefly, these variants include:

(i) Deletion: As in other varieties of French, final clusters with liquids are typically simplified, especially when followed by a consonant-initial word. Though it is possible to say the compound boucle d'oreille 'earring' slowly and carefully as [buklədərejə], it is virtually always pronounced as [bukdərej]. Similarly the phrase l'autre gars 'the other guy' could be pronounced as [lotrəgo], but is in fact characteristically rendered as [lotgo]. Note that the careful pronunciation, using schwa, involves resyllabifying such that the $/ \mathrm{r} / \mathrm{s}$ in these cases are actually in onsets. Deletion is also usual before a pause. Thus Lise R. (038), ${ }^{6}$ age seventeen in 1971, in answer to a question about whether her neighborhood has changed much since she was a small child, says Bien peut-être ('well maybe'), deleting the final $/ \mathrm{r} /$ in this case as in all others in pause and preconsonantal environments. Québécois French also frequently deletes liquids before a vowel in a following word. For example, Yannick C. (126), seventeen years old in 1984, said Nous aut(res) on va aller viv(re) avec l'ami de ma mère ('We're going to go live with my mother's boyfriend'), deleting the $/ \mathrm{r} / \mathrm{s}$ in the parenthesized material. This was at the beginning of the interview when Yannick was speaking rather carefully.

(ii) Vocalization: In codas, especially after a final diphthong or lengthened vowel, /r/ may be lenited to the point of vocalization. Examples of words where vocalization frequently occurs include boire 'to drink', père 'father', pour 'for', and sur 'on'.

(iii) RETROFLEX / $/ \mathrm{r}$ is a fairly rare variant that occurs sporadically, often in Englishassociated words, especially although not only proper nouns like Steinberg (a now-defunct supermarket chain) and Montréal (Tousignant 1987b). In coda position, retroflex /r/ occurs most frequently after the rounded vowels /œ/, as in peur 'fear', congélateur 'freezer', and Steinberg, and /y/, as in sûr 'certain' and pur 'pure'.

Since these forms did not involve tongue contact with either the alveolar ridge or the velar/uvular region, they were not considered to represent consonantal targets and were therefore not included in the quantitative analysis. We follow the practice of the earlier studies cited above in this regard. Between 1950 and 1970, canonical /r/ in Montreal began to change, with the dorsal [R] making strong inroads. The conclusion that by 1970 [r] was in 'rapid regression' (Santerre 1978) was confirmed in an apparenttime calculation by Clermont and Cedergren (1979), henceforward C\&C, who found that the innovative [R] was increasingly common among speakers below age thirty-

$d u$ Canada, all the data points from the Eastern Quebec region of Nicolet, Rivard's original home, were registered as dorsal $[R]$ in the 1951 survey.

${ }^{6}$ As with all the other speaker names cited in this article, 'Lise' is a pseudonym. Speaker identification numbers from the original corpus are also provided since many speakers are referred to by number only in previous publications. 
five. Figure 1, adapted from that study, represents their study of all 120 speakers in 1971.

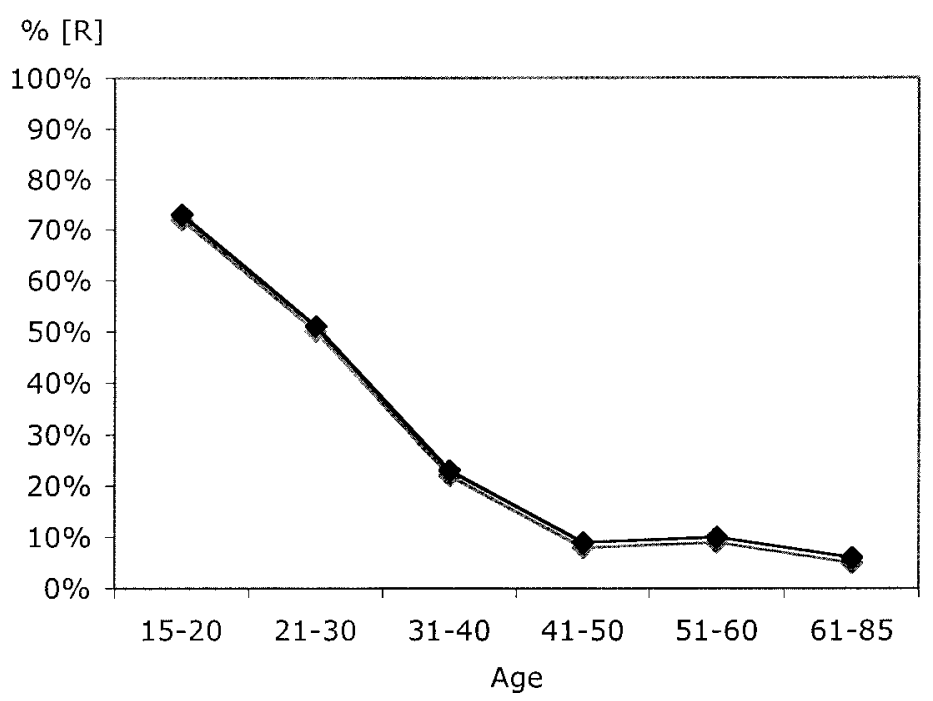

FIGURE $1 .[R] /([R]+[\mathrm{r}]$ ) by age for 120 speakers in 1971, plotted by age group (data from Clermont \& Cedergren 1979).

Summarizing the results from that study, Cedergren reports that a multiple regression with rate of $[R]$ use as the dependent variable shows that 'the single most important factor ... was the speakers' age, followed by social class membership, sex, and educational level of attainment' (1988:49). Cedergren verified these apparent-time inferences, showing that change had already begun at least a decade earlier, using a sample of twenty-nine interviews from the Bibeau-Dugas corpus established in 1963.

Our first attempt at tracing change since 1971 was strictly limited to a panel comparison (Sankoff, Blondeau, \& Charity 2001, henceforward SBC), and its central issue was the lability of speakers' linguistic systems in later life. To this end, we considered data from the 1984 and 1995 restudies of Montreal (Thibault \& Vincent 1990, Vincent et al. 1995). We examined speaker trajectories for fourteen speakers recorded in both 1971 and 1984, for all twelve of the 1971 speakers who were carried through 1984 to 1995 , and for the two additional younger speakers added in 1984 who were also reinterviewed in 1995.

In the current article, we use an expanded panel, and also make trend comparisons of speakers sampled in 1971 and 1984, allowing us to document both real-time change in the speech community as well as the trajectories of $/ \mathrm{r} /$ pronunciation of a number of individual speakers who were followed across that time span. We focus on the social factors that differentiate speakers in terms of their use of the two canonical variants, $[\mathrm{r}]$ and $[\mathrm{R}]$. The phonological factors that partially condition the alternation between these variants are dealt with in Sankoff \& Blondeau 2008, where we also consider stylistic factors, which prove to be almost without influence on the alternation.

3. Design and methodology of the CuRRent study. It is widely acknowledged that the most reliable method for studying language change in a community is that of the trend study (Trudgill 1988, Labov 1994). In the ideal case, the followup study would resample the community, using the same sampling criteria as the first (de Paiva \& 
Duarte 2003, Zilles 2005). In our case, the 1984 survey was designed mainly as a panel study (Thibault \& Vincent 1990); however, the twelve new younger speakers who were added (see below) were used as a nucleus in designing matched subsamples that allow us to make trend comparisons. The logic of these comparisons, involving selected subsamples of thirty-two speakers each (see Figure 2), is explained in §§3.1-3.4.

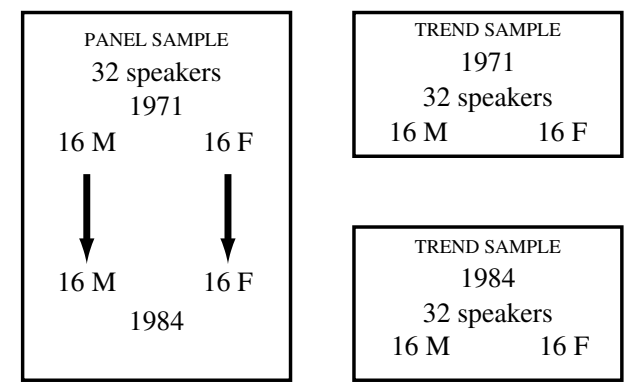

FIGURE 2. Design of the trend and panel samples for the current study.

The 1971 sociolinguistic study of Montreal consisted of a random sample of 120 speakers, stratified by age, sex, and social class (Sankoff \& Sankoff 1973). In 1984, Thibault and Vincent succeeded in relocating and reinterviewing sixty of the original interviewees, making this the largest and most representative panel study in sociolinguistics. Since the youngest speakers of 1971 were by then twenty-eight years old, they added twelve new speakers between age fifteen and twenty-five, again stratified according to sex and socioeconomic level. To examine change across individual lifespans, we could have studied all sixty of the reinterviewed subjects, comparing their 1971 data with their 1984 data. Similarly, we first thought that we might study changes at the community level by comparing the sixty speakers of 1971 who were NOT reinterviewed with the different sixty of 1984 . However, the subsample of speakers who were reinterviewed was not comparable to those who were, according to their relevant social characteristics. First, the mean age of the sixty reinterviewed speakers was thirteen years older than the speakers of 1971. Second, as a group, the reinterviewed speakers overrepresented people of a higher social class. ${ }^{7}$ Last, we decided to sample from the ninety-five speakers age fifty-seven and under in 1971, mainly on the grounds that relatively few speakers above that age appeared in the reinterviews of 1984 . We weighted our subsamples toward speakers under forty, who would be most reliably resampled.

In order to be able to construct matched subsamples of different speakers, we set up a sampling stratification scheme that would allow us to resample from the pool of available speakers according to age, sex, and social class. The largest subsamples we could create, given the constraints described above, consisted of thirty-two individuals each, as shown in Tables 3-6 below. To represent a range of social classes, we divided

\footnotetext{
${ }^{7}$ Twenty of the original subjects of the 1971 sample were selected from eight census tracts with the lowest mean family income in the city, a neighborhood known as 'Centre Sud' near the Port of Montreal containing some 27,000 people. Between that time and 1984, a massive highway project had destroyed most of this neighborhood, and it was very difficult to locate former residents (though Thibault and Vincent were successful in some cases). It was obviously easier to relocate professional people who could be found through their business addresses even if they had changed their place of residence.
} 
the population into three groups according to their scores on the LINGUISTIC MARKET (LM) index. ${ }^{8}$

3.1. The panel subsample. Constructing a subsample for the panel of speakers to be followed between 1971 and 1984 necessarily involved selecting from among the sixty original speakers who were reinterviewed in 1984. Setting aside those over age fifty-eight as described above, we selected thirty-two speakers to fill the subsample grid. For most cells, we had more than the required number of speakers available, so our choice was determined by two factors. First, we always selected the most voluble speakers (those with the longest interviews), so as to be sure to have plenty of tokens for analysis. Second, if the sound quality for any speaker's recording was poor (unfortunately the case for three or four of the speakers we initially selected), that person was replaced by another speaker with matching social characteristics. The structure of the final 1971 panel sample is provided in Table 3.

\begin{tabular}{|c|c|c|c|c|c|c|c|}
\hline & & & & & & & \\
\hline & WC & & $\mathrm{LMC}$ & -59) & UM & $+)$ & \\
\hline AGE & $\mathrm{M}$ & $\mathrm{F}$ & M & $\mathrm{F}$ & $\mathrm{M}$ & $\mathrm{F}$ & TOTAL \\
\hline $15-24$ & 2 & 2 & 2 & 2 & 3 & 2 & 13 \\
\hline $25-39$ & 3 & 2 & 1 & 2 & 2 & 2 & 12 \\
\hline $40-56$ & 1 & 2 & 1 & 1 & 1 & 1 & 7 \\
\hline TOTAL & 6 & 6 & 4 & 5 & 6 & 5 & 32 \\
\hline
\end{tabular}

TABLE 3. Composition of 1971 panel subsample by age, sex, and social class (scores on linguistic market index divided into 3 groups, corresponding to Working Class, Lower Middle Class, and Upper Middle Class).

By definition, the panel included a constant group of speakers, so the 1984 panel comprised the same individuals, thirteen years older, and analyses of the panel compare the 1984 data to the same individuals' data from 1971. Since the youngest panel speakers were twenty-eight years old in 1984, there was no one in the youngest age group of the subsample grid for that year, as indicated in Table 4. The oldest 1971 panel speaker, Lucille R. (084), was fifty-six in 1971 and sixty-nine in 1984.

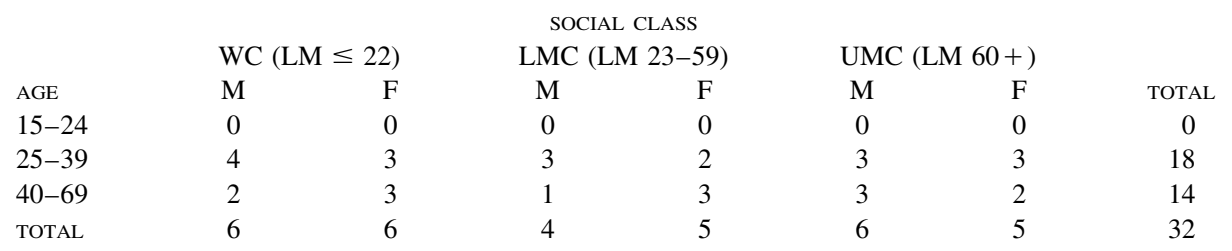

TABLE 4. Composition of 1984 panel subsample by age, sex, and social class (scores on linguistic market index divided into 3 groups, corresponding to Working Class, Lower Middle Class, and Upper Middle Class).

\footnotetext{
${ }^{8}$ Having discovered that the six-point socioeconomic index of Thibault and Vincent (1990) and the linguistic market index devised by D. Sankoff and Laberge (1978), on which scores between 0 and 100 were assigned to every speaker in 1971 , were highly correlated $(r=.71)$, we decided to use the more highly gradated LM index in choosing our subsample. In selecting the speakers, we cut the scale in such a way as to represent approximately one-third of the speakers in each group, which are labeled (as a heuristic) in Tables 3-6 as UMC (Upper Middle Class), LMC (Lower Middle Class), and WC (Working Class). The UMC group certainly also includes a number of Upper Class speakers; and the WC group includes many members of the underclass-people who in 1971 were unemployed, some of whom were illiterate, had a year or less of formal schooling, and had lived their entire lives on welfare.
} 
3.2. The TREnd Subsamples. The subsample from 1971 that would be used as a basis for trend comparisons had to be selected from among the sixty speakers who were NOT reinterviewed in 1984. From this pool of speakers, using the same criteria outlined above, we selected thirty-two individuals, stratified by age, sex, and social class as shown in Table 5. For 1971, then, our trend and panel subsamples were selected from the two halves of the sample of 120 according to the same criteria. Although the two halves were somewhat disparate for reasons explained above, the subsampling criteria allowed us to select subsamples that matched each other fairly closely, as becomes evident in Tables 8 and 9 below.

\begin{tabular}{|c|c|c|c|c|c|c|c|}
\hline & \multicolumn{6}{|c|}{ SOCIAL CLASS } & \multirow[b]{3}{*}{ TOTAL } \\
\hline & \multicolumn{2}{|c|}{$\mathrm{WC}(\mathrm{LM} \leq 22)$} & \multicolumn{2}{|c|}{ LMC (LM 23-59) } & \multicolumn{2}{|c|}{ UMC (LM 60+) } & \\
\hline AGE & M & $\mathrm{F}$ & M & $\mathrm{F}$ & M & $\mathrm{F}$ & \\
\hline $15-23$ & 2 & 2 & 4 & 3 & 3 & 2 & 16 \\
\hline $24-39$ & 2 & 2 & 1 & 1 & 1 & 2 & 9 \\
\hline $40-56$ & 1 & 1 & 1 & 2 & 1 & 1 & 7 \\
\hline TOTAL & 5 & 5 & 6 & 6 & 5 & 5 & 32 \\
\hline
\end{tabular}

TABLE 5. Composition of 1971 trend subsample by age, sex, and social class (scores on linguistic market index divided into 3 groups, corresponding to Working Class, Lower Middle Class, and Upper Middle Class).

The trend subsample for 1984 had to be selected as if we had returned to the speech community and taken a new sample according to the criteria of 1971 . We of course included the twelve younger speakers who were added to the study in 1984, matching them to their 1971 age mates. There were, however, only eleven speakers age twentythree and under in 1984, compared to sixteen in that age range for the 1971 trend subsample. For the middle age group, we included the one new speaker age twentyfive, and had to fill out this group from the ranks of the younger reinterviewed speakers. Luckily, there were a good number of these people under age forty in 1984. Since the 1984 trend subsample was to be compared to its 1971 counterpart involving different speakers, but would not be directly compared to the 1984 panel subsample, it was economic to complete the 1984 trend subsample with speakers who were also part of the 1984 panel. The 1984 trend subsample, selected to match its 1971 counterpart insofar as was possible, is shown in Table 6.

\begin{tabular}{|c|c|c|c|c|c|c|c|}
\hline & & & & & & & \\
\hline & WC & & LMC & -59) & UM & $+)$ & \\
\hline AGE & M & $\mathrm{F}$ & M & $\mathrm{F}$ & M & $\mathrm{F}$ & TOTAL \\
\hline $15-23$ & 2 & 2 & 2 & 2 & 1 & 2 & 11 \\
\hline $24-39$ & 3 & 3 & 2 & 2 & 1 & 2 & 13 \\
\hline $40-56$ & 2 & 2 & 1 & 1 & 1 & 1 & 8 \\
\hline TOTAL & 7 & 7 & 5 & 5 & 3 & 5 & 32 \\
\hline
\end{tabular}

TABLE 6. Composition of 1984 trend subsample by age, sex, and social class (scores on linguistic market index divided into 3 groups, corresponding to Working Class, Lower Middle Class, and Upper Middle Class).

3.3. Data CODING AND ANALYSIS. For each speaker in each year, our goal was to code approximately one hundred tokens, beginning about ten minutes into the interview (usually starting at the fifth page of the transcript) and continuing to code each $/ \mathrm{r} /$ that occurred. For many speakers, however, deleted and vocalized /r/ constituted a fairly large proportion of the tokens, and for this reason we often increased the total token size to about 120 , sometimes more. We could usually locate the desired number of 
tokens within about twenty to thirty minutes of speech. Two coders listened to each tape and noted codes on separate spreadsheets, after which the number of instances of $[R]$ and $[r]$ were noted and the percentage calculated as $[R] /([R]+[r])$, setting aside the other variants in this calculation. This procedure is illustrated in Table 7, which provides the codings of Hélène Blondeau and Sarah Moretti for Bernard L. (087'71). All variants of $/ \mathrm{r} /$ were coded for each speaker, but following $\mathrm{C} \& \mathrm{C}$, only canonical $[R]$ and $[\mathrm{r}]$ entered into our calculations.

$\begin{array}{lcccccccc}\text { CODER } & {[\mathrm{R}]} & {[\mathrm{r}]} & \text { VOCALIZED } & \text { DELETED } & \text { RETROFLEX } & \text { INDISTINCT } & \text { TOTAL } & {[\mathrm{R}] /([\mathrm{R}]+[\mathrm{r}])} \\ \text { Blondeau } & 39 & 44 & 29 & 16 & 2 & 7 & 137 & 47.0 \% \\ \text { Moretti } & 30 & 28 & 23 & 35 & 4 & 13 & 133 & 51.7 \%\end{array}$

TABle 7. Codings for Bernard L. in 1971 by Hélène Blondeau and Sarah Moretti.

We then ran a chi-square test on the $2 \times 2$ table highlighted on the left, and if the difference between the two coders was not significant at the 0.05 level, as in this case, we usually considered the value for that speaker in that year to be the mean of the two codings. ${ }^{9}$ If the codings were significantly different, a third coder recoded the data, after which two of the coders (always involving at least one of the two coauthors of this article) listened to the tape together and reconciled the differences. There were two major sets of problem cases. First, tokens with a very weak dorsal articulation might be heard as 'vocalized' or 'indistinct' by one coder and as the dorsal [R] by another coder; joint relistening usually resolved these cases. The second type involved the manner of articulation. Both apical and uvular /r/ can be trilled, and trills made it very difficult to hear the place of articulation. Spectrographic examination with Praat did not help increase reliability on the whole, and we therefore followed the original procedures of $\mathrm{C} \& \mathrm{C}$ and of Tousignant, using auditory coding supplemented by spectrographic analysis in only a small number of problem cases. Since (as in the case illustrated in Table 7) the two coders often arrived at slightly different total numbers of tokens in listening to the same stretch of speech, we can provide only an approximation rather than a definitive count of the total number of tokens coded for this project. Our estimate is that the results given in this article represent the analysis of approximately 12,400 tokens, or approximately 115 per speaker sample.

3.4. The LOGIC OF COMPARISOns. We selected our panel and trend subsamples from the 120 speakers of 1971 using the same criteria of age, sex, and social class as described above. Drawing two separate stratified subsamples from the same community, we would hope to derive the same results. In analyzing the data, we thus first compare the two 1971 subsamples to see whether indeed their behavior is matched in the way we would expect. We make separate comparisons across older and youngers speakers in the subsamples. Next, we look at the panel as a group and examine the extent to which these individuals did or did not change. Finally, the panel's behavior is set in the context of the real-time change as revealed by comparing the two trend samples.

4. The situation in 1971. The linguistic situation in 1971 with respect to the major variants of $/ r$ / in Montreal was well documented (C\&C, Santerre 1978, Tousignant 1987a, SBC). C\&C demonstrated that speakers of higher socioeconomic status and

\footnotetext{
${ }^{9}$ In this particular case, Alice Goffman had also coded the same recording and her result was $49 \%$ [R]. Gillian Sankoff had occasion to listen to that tape again later in the coding procedure, and reconciled the three codings. The data point finally entered for Bernard L. in 1971 was in fact not the mean of all three, but the figure of $47 \%[\mathrm{R}]$ originally arrived at by Hélène Blondeau.
} 
younger speakers were most likely to use a higher proportion of the innovative [R] variant. In selecting our two subsamples from among the 120 speakers they studied, the first question we ask in the analysis is whether we are justified in treating the two 1971 samples of thirty-two speakers as two halves of a split sample of sixty-four. Can we reasonably think of them as two sets of people drawn at random to represent the same community? Tables 8 and 9 make the comparison in terms of means within each subsample.

$\begin{array}{lcccc}1971 \text { PANEL SPEAKERS } & \text { AGE RANGE } & \text { MEAN AGE } & \text { MEAN LM } & \%[\mathrm{R}] \\ 16 \text { younger } & 15-24 & 19.1 & 47.1 & 63.8 \% \\ 16 \text { older } & 25-56 & 37.1 & 43 & 41.3 \% \\ \text { All 32 speakers } & 15-56 & 28.1 & 45 & 52.5 \%\end{array}$

TABLE 8. Mean social characteristics and mean [R] \%, 1971 panel sample.

$\begin{array}{lcccc}1971 \text { TREND SPEAKERS } & \text { AGE RANGE } & \text { MEAN AGE } & \text { MEAN LM } & \%[\mathrm{R}] \\ 16 \text { younger } & 15-24 & 18.8 & 44.5 & 68.5 \% \\ 16 \text { older } & 25-56 & 39.2 & 32.6 & 34.3 \% \\ \text { All 32 speakers } & 15-56 & 29.0 & 38.5 & 51.4 \%\end{array}$

TABLE 9. Mean social characteristics and mean [R] \%, 1971 trend sample.

We have more to say later about individual speakers. However, mean results for the two groups show that they are indeed quite comparable. Both samples contained thirtytwo speakers, sixteen men and sixteen women, and both contained from ten to twelve speakers in each of the three socioeconomic groups. The mean age of the 1971 panel speakers was 28.1; that of the 1971 trend speakers was 29 . The socioeconomic linguistic market index values were 45 in the case of panel speakers and 38.5 for trend speakers. Although we tried hard to select the most closely matched sample, we ended up with speakers of a slightly higher socioeconomic level in the panel, reflecting the fact that such speakers were somewhat easier to relocate in the 1984 study. ${ }^{10}$

In selecting our subsamples, we made sure to represent three age groups of speakers, but for analytical purposes, we divide each subsample into sixteen younger and sixteen older speakers, whose age ranges are provided in the relevant tables. In both subsamples, speakers age twenty-four and under show means of [R] usage considerably higher than speakers twenty-five and older. The mean [R] percentages for older speakers in the two samples are seven percentage points apart (41.3\% for the panel sample and $34.3 \%$ for the trend sample), whereas the younger speakers' means are within five percentage points of each other ( $63.8 \%$ for the panel sample and $68.5 \%$ for the trend sample). Grouping younger and older speakers together in each subsample, the means are only one percentage point apart (52.5\% for the panel and 51.4\% for the trend sample). This result allows us to proceed with confidence in studying change over time.

5. Change across the lifespan: the panel SPEAKers over time. An initial look at the panel as a group can be obtained by considering the group means for the 1984 panel speakers: the thirty-two individuals of the 1971 panel sample, all thirteen years older, as shown in Table 10.

$\begin{array}{lcccc}1984 \text { PANEL SPEAKERS } & \text { AGE RANGE } & \text { MEAN AGE } & \text { MEAN LM } & \%[\mathrm{R}] \\ 16 \text { younger } & 29-37 & 32.1 & 47.1 & 77.8 \% \\ 16 \text { older } & 38-69 & 50.1 & 43 & 50.8 \% \\ \text { All 32 speakers } & 29-69 & 41.1 & 45.1 & 64.2 \%\end{array}$

TABLE 10. Mean social characteristics and mean [R] \%, 1984 panel sample.

${ }^{10}$ This point is elaborated in $n .7$. 
Comparing Table 10 with Table 8 reveals that as a group, these speakers have increased their use of [R] over the period. The younger speakers' group mean was $63.8 \%$ in 1971; these same people show a mean of $77.8 \%$ in 1984, an increase of more than ten percentage points. Perhaps more surprising, given the widespread acceptance of the idea that adults' linguistic systems are relatively stable, is the increase of almost ten percentage points, from $41.3 \%$ to $50.8 \%$, for the older group. The means, however, give a misleading picture of the sample members as a homogeneous group. As we discovered in examining the smaller panel sample across the twenty-four-year span from 1971 to 1995 (SBC), the increase is far from uniform when we look at individuals. To separate the speakers into those who were stable and those who changed, we did a chi-square test comparing each speaker's total apical and dorsal /r/ tokens in their 1971 and 1984 samples. Ten of the thirty-two speakers were designated as having changed significantly over the period, nine in the expected direction. The tenth speaker, Christine Q. (004), appears to be a counterexample, since her change was in the opposite direction, from $92 \%$ to $87 \%$ [R]. However, the chi-square probability of 0.05 cannot be considered since one would expect at least one such movement by chance in a group of thirty-two speakers. Further, since she remains in the near-categorical range of Table 11 , we treated her as one of those speakers who remained stably in that category across time.

We consider first in Table 11 a comparison between the speakers who were stable over time: the ten (including Christine Q.) who maintained near-categorical $[R]$, the innovative variant, and the ten who maintained near-categorical [r], the traditional Montreal variant. The two groups have very different social profiles: the group we label 'early adopters' of the innovative form are much younger (just a little more than half the age of the speakers who retain the traditional form) and have a higher mean social-class index on the linguistic market scale. More striking is the very disproportionate sex ratio: drawn from a pool of sixteen male and sixteen female speakers, eight of ten early adopters are female; and seven of ten traditionalists are male, a statistically significant difference. ${ }^{11}$ Gender difference is then a third variable, in addition to age and social class, that is important in determining which speakers are early adopters of the innovative form.

\begin{tabular}{|c|c|c|c|c|c|c|}
\hline & & & & & MEAN & SEX \\
\hline & & TRAJECTORY & NO. OF & MEAN & AGE & RATIO \\
\hline RANGE TYPE & RANGE OF $[\mathrm{R}]$ & TYPE & SPEAKERS & LM & 1971 & $\mathrm{~F}: \mathrm{M}$ \\
\hline $\begin{array}{c}\text { categorical or near- } \\
\text { categorical }[R]\end{array}$ & $85-100 \%$ & stable & 10 & 39.1 & 16.9 & $8: 2$ \\
\hline $\begin{array}{l}\text { categorical or near- } \\
\text { categorical }[\mathrm{r}]\end{array}$ & $0-17 \%$ & stable & 10 & 29.0 & 30.3 & $3: 7$ \\
\hline
\end{tabular}

TABLE 11. The 20 stable speakers who remained categorical or near-categorical users of one of the two variants across the study, 1971-1984.

The twelve remaining speakers were those whose behavior was more variable. Midrange speakers are defined as those whose use of [R] fell between $17 \%$ and $84 \%$ at either period. The mid-range speakers stand out in Figure 3, which plots the percentage of $[\mathrm{R}]$ for each of the panel speakers in both 1971 (filled diamonds) and 1984 (hollow squares). The overall increase of 12.3 percentage points is clearly not attributable to most speakers having slightly increased their use of the innovative variant. Rather, the increase is due to nine of the thirty-two individual speakers having made a fairly dra-

${ }^{11}$ The significance level of $p<0.05$ was calculated by Fisher's exact test. 
matic shift between 1971 and 1984. The trajectories of these nine individuals are designated by arrows connecting their 1971 with their 1984 data points.

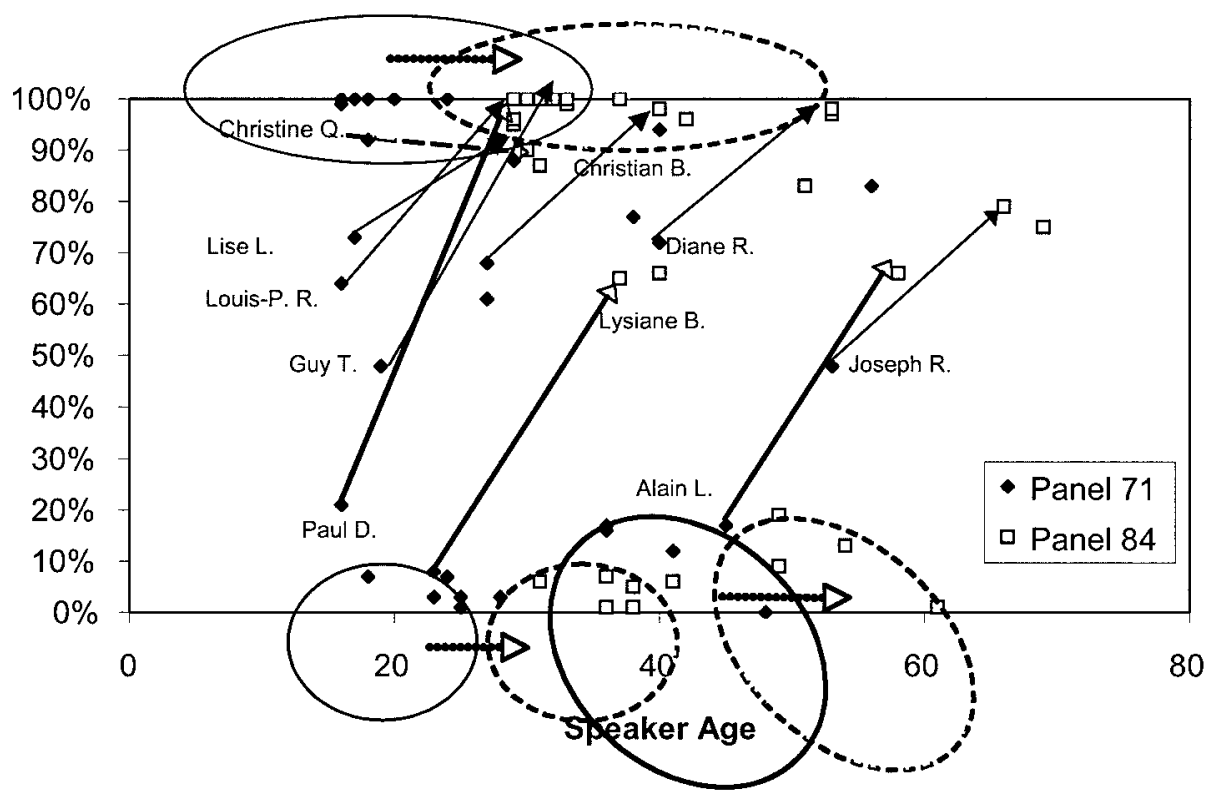

FIGURE 3. Individual percentages of $[R] /([R]+[\mathrm{r}])$ for the 32 panel speakers for 1971 and 1984. Trajectories plotted for all speakers who showed a significant difference between the two years.

At the bottom of the graph, we see two groups of the 1971 speakers in the ellipses: a tight cluster of seven individuals under age thirty, none of whom uses more than $10 \%[R]$, and another group of five speakers between the ages of thirty-five and fifty, and who range between $0 \%$ and $17 \%$. Ten of these twelve people form the stable group of Table 11 in their use of the conservative form. Their 1984 values are displayed in the two dotted ellipses to the right of each of the 1971 groups. Two of them, however, Lysiane B. (007) and Alain L. (104), make substantial changes, abandoning the virtually categorical conservative pattern they displayed in 1971. Along with the other midrange speakers, their data appears individually in Table 12. Lysiane and Alain are among the nine speakers whose trajectories appear in Fig. 3.

A majority of mid-range speakers in 1971 (seven out of ten) had moved to the categorical or near-categorical use of innovative [R] by 1984. They are people we call 'later adopters' of the innovative variant. Five of the seven are young; five of the seven are male. As a group, we would characterize their behavior as catching up with their peers, the early adopters. The next three people listed in Table 12 are those mid-range speakers who were stable, somewhat older, behaving more as we had expected older individuals to behave. Of note is that one of them, André L. (065), a professional actor age twenty-seven when we met him in 1971, was the only speaker who exhibited stylistic variation (Sankoff \& Blondeau 2008). In 1995 he maintained virtually the same overall level of [R] as he had in 1984: 69\%. At the bottom of the table are the two individuals who moved from virtually categorical use of [r] to dominant use of [R], occupying the upper part of the variable range. Lysiane B. (007) is a case of exceptional upward social mobility, a twenty-four-year-old factory worker when we met her in 1971, a businesswoman in 1984, and when last interviewed in 1995, a successful realtor. 


SPEAKER
Louis-Pierre R. (092)
Paul D. (064)
Lise L. (071)
Guy T. (088)
Christian B. (025)
Diane R. (066)
Joseph R. (075)
André L. (065)
Henriette N. (015)
Lucille R. (084)
Lysiane B. (007)
Alain L. (104)

$\begin{array}{ccccr} & \text { AGE } & \%[\mathrm{R}] & & \%[\mathrm{R}] \\ \text { TRAJECTORY TYPE } & 1971 & 1971 & & 1984 \\ \text { variable } \rightarrow \text { categorical } & 16 & 64 \% & < & 100 \% \\ \text { variable } \rightarrow \text { categorical } & 16 & 21 \% & < & 95 \% \\ \text { variable } \rightarrow \text { categorical } & 17 & 73 \% & < & 90 \% \\ \text { variable } \rightarrow \text { categorical } & 19 & 48 \% & < & 100 \% \\ \text { variable } \rightarrow \text { categorical } & 27 & 68 \% & < & 98 \% \\ \text { variable } \rightarrow \text { categorical } & 40 & 72 \% & < & 97 \% \\ \text { variable } \rightarrow \text { categorical } & 53 & 48 \% & < & 79 \% \\ \text { stably variable } & 27 & 61 \% & \text { n.s. } & 66 \% \\ \text { stably variable } & 38 & 77 \% & \text { n.s. } & 83 \% \\ \text { stably variable } & 56 & 83 \% & \text { n.s. } & 75 \% \\ \text { categorical } \rightarrow \text { variable } & 24 & 7 \% & < & 65 \% \\ \text { categorical } \rightarrow \text { variable } & 45 & 17 \% & < & 66 \%\end{array}$

TABLE 12. Percentages of [R] use for 12 speakers whose [R] use fell into the mid-range of variation in either or both 1971 and 1984. Note that 'categorical' here refers to categorical or near-categorical.

Although her own characterization of the major change in her speech over this period is that she has learned English, it is clear that she has adopted many features characteristic of middle class speakers during her adult life (Blondeau et al. 2002). As far as Alain L. (104) is concerned, we were quite surprised that a man of forty-five would have shown such a remarkable change by the time he was fifty-eight. A car salesman, Alain was interviewed in 1984 at the car dealership where he worked, and much of the talk focused on questions of language and of taste. To attribute his relatively high level of [R] to formality, however, is probably too hasty. We have been unable to show stylistically conditioned variation for any speaker other than the professional actor André L. (065), who was part of the long-term longitudinal sample followed from 1971 through 1995 and who retained his upper mid-range value throughout (SBC, Sankoff \& Blondeau 2008).

Table 12 and Fig. 3 show clearly that the mid-range use of both variants is not stable. Not only do most speakers cluster at the top or the bottom of the range, but mid-range speakers also tend very strongly to become categorical over time.

We return to a discussion of the matter of individual stability/instability and related issues in the final section. To conclude our study of the panel results, we find that they confirm our previous research on a smaller sample (SBC). Looked at in terms of the critical age, the evidence from this panel is that twenty-three of the thirty-two speakers $(72 \%)$ showed stability over the period of their post-fifteen-year-old lives that we examined; the other nine $(28 \%)$ increased their use of the innovative form significantly. Perhaps a more telling comparison is to look at the pool of speakers who had not yet adopted the innovative form in 1971. Of the twenty-two speakers who might have changed toward the innovative form, nine, or $41 \%$, did so.

We might now ask: is $41 \%$ a lot, or a little, in terms of our expectations about speakers' malleability in adult life? Are the speakers who make this adult transition the leaders of the change in the community? In the next section, in which we present the results of the trend study, we put these questions into the community perspective.

6. Change in the COMmunity: the evidence of trend COMParisons. We noted in $\$ 3.2$ (comparing Tables 5 and 6) that the 1984 trend sample was quite similar to the 1971 trend sample in terms of the social characteristics of the speakers. In selecting that subsample, however, we were not able to match the numbers of 1971 for the 
youngest group, since only twelve new young speakers were interviewed in 1984, one of whom was twenty-five years old. When distributing our trend sample of 1984 according to the two age groups selected for analysis, there is an unequal number of 'younger' and 'older' speakers. For this reason, we pay most attention to the comparison of younger to younger, and older to older, in tracing the trends between 1971 and 1984. The figures for older and younger speakers reported in Table 9 are repeated in Table 13, along with the comparable results from the 1984 subsample.

$\begin{array}{lcccc}\text { TREND SUBSAMPLES } & \text { AGE RANGE } & \text { MEAN AGE } & \text { MEAN LM } & \%[\mathrm{R}] \\ 16 \text { younger } 1971 & 15-24 & 18.8 & 44.5 & 68.5 \% \\ 11 \text { younger } 1984 & 15-24 & 17.9 & 60.9 & 92.5 \% \\ 16 \text { older } 1971 & 25-61 & 39.2 & 32.6 & 34.3 \% \\ 21 \text { older } 1984 & 25-61 & 38.6 & 40.3 & 74.9 \%\end{array}$

TABLE 13. Mean social characteristics and mean [R] \%, 1971 and 1984 trend subsamples.

The eleven younger speakers who were added to the sample in 1984 were a good match for their 1971 counterparts in age, but we note an increase in the mean LM scores, at least some of which is attributable to overall socioeconomic change in the community. By 1984, the economic recession of the early 1970s had turned around, and more families could afford to keep their teenagers in school longer. Although one would expect higher [R] scores for speakers of higher socioeconomic status, the jump from $68 \%$ [R] in 1971 to $92.5 \%$ in 1984 among speakers under twenty appears to represent a real-time change in the community. Perhaps even more significantly, the twenty-five-to-sixty-one-year-old trend subsample in 1984, more closely matched for socioeconomic status with their 1971 counterparts, shows an even greater increase: from $34.3 \%$ in 1971 to $74.9 \%$ in 1984 . Adults of working age in the Montreal community in 1971 were quite likely to be predominant users of [r], but this was no longer the case in 1984. These trend comparisons clearly indicate that change was vigorous in the community in the 1970s and 1980s.

The trend study, representing a real-time reassessment of the community after a thirteen-year interval, is the basis for assessing real-time change. As such, the community mean indicates a massive shift toward the replacement of $[\mathrm{r}]$ by $[\mathrm{R}]$ during this period. Although the mean increase of panel speakers seemed to indicate progress toward the incoming form, the trend study confirms that at the community level, the rate of change is much greater, as is evident from the comparisons in Table 14.

\begin{tabular}{lcccc} 
& \multicolumn{2}{c}{ MEAN [R], YOUNGER SPEAKERS } & \multicolumn{2}{c}{ MEAN [R], OLDER SPEAKERS } \\
& $\begin{array}{c}\text { Panel, same } \\
\text { speakers }\end{array}$ & Two separate trend & Panel, same & Two separate trend \\
1984 & $77.8 \%$ & samples & speakers & samples \\
1971 & $63.8 \%$ & $92.5 \%$ & $50.7 \%$ & $74.9 \%$ \\
mean increase & 14.0 & $68.5 \%$ & $41.3 \%$ & $34.3 \%$ \\
& & 24.0 & 9.4 & 40.6
\end{tabular}

TABLE 14. Comparison of trend and panel subsamples over time.

Our examination of panel speakers as a group across time confirmed that such group means may give a misleading picture of what is going on. The examination of individual speakers led us to infer that the change is being implemented by people who alter their pronunciation quite rapidly, rather than a steady, incremental raising of levels across individual lifespans. An examination of the individual speakers in the two trend samples further illuminates these initial inferences, as can be seen in Figure 4.

Figure 4 indicates that the real-time change reflected in the community means of Table 13 is a product of a very different distribution of speakers in 1971 and 1984. 


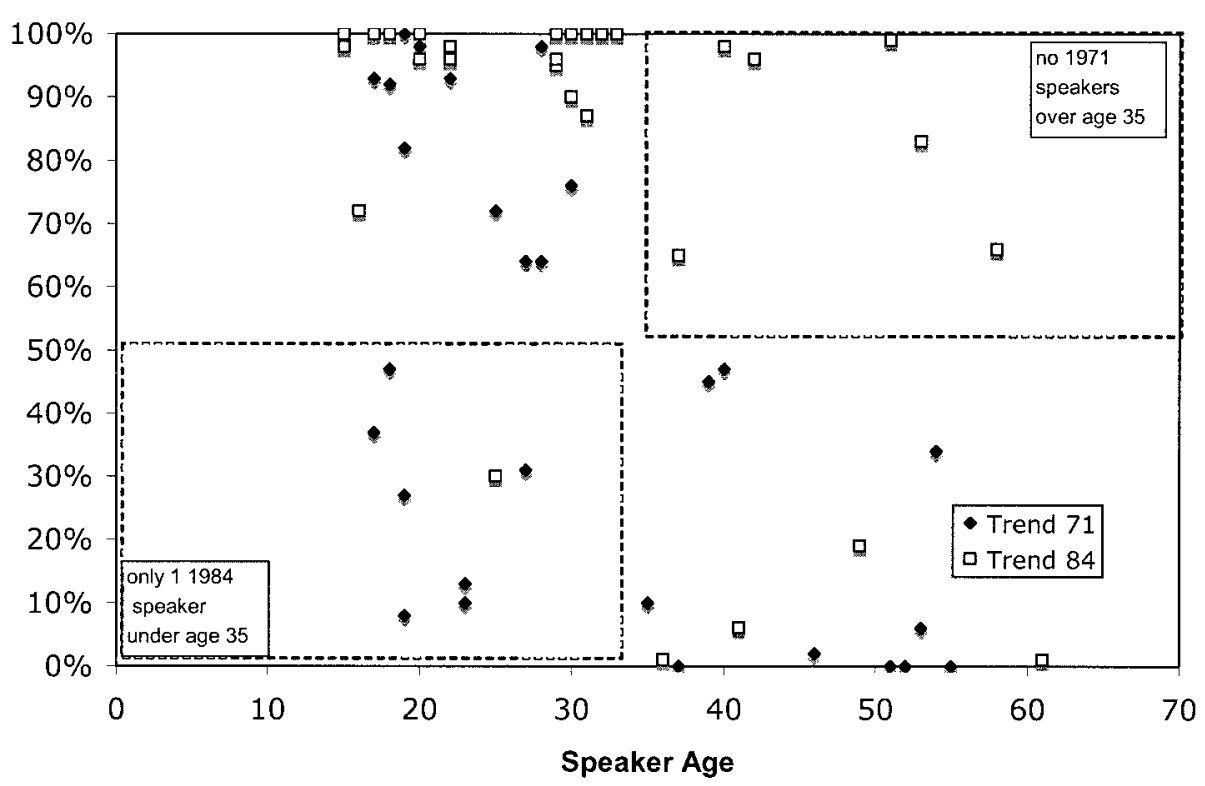

FIGURE 4. Individual percentages of $[R] /([R]+[\mathrm{r}])$ for the 32 trend speakers for 1971 and for the 32 different trend speakers for 1984 .

Seven speakers under age thirty-five in 1971 (filled diamonds inside the dotted rectangle at the lower left) were predominant users of the conservative [r]; and only six were in the near-categorical [R] range on the upper left. By 1984, only one speaker under age thirty-five was a predominant user of the conservative form, and with one mid-range exception, all of the other younger speakers were clustered within the near-categorical $[R]$ range. Among those over thirty-five, we see that in 1971, no speaker showed more than $50 \%[\mathrm{R}]$; most were clustered at the bottom of the figure in the categorical $[\mathrm{r}]$ range. In contrast, by 1984 there were six majority users of [R] among those older than thirty-five.

The panel study showed that early adopters remained stable across the 1971-1984 period. Once having adopted innovative [R], they continued as categorical or nearcategorical users of this form. By the time they got to be age thirty-five and older, these early adopters were joined by a number of later adopters, who caught up with the change in later life. But whereas many younger speakers in 1971 were still majority users of the conservative form, this was no longer the case in 1984.

7. The PROCESS OF CHANGE.

7.1. The RESUlts OF OUR STUDY OF $[\mathrm{r}] \rightarrow[\mathrm{R}]$. What generalizations can be drawn from the detailed results reviewed in $\S \S 5$ and 6 , and how do they relate to our understanding of language change? Let us begin by summarizing the major observations drawn from the trend and panel studies, along with the results of C\&C (1979) based on the entire sample of 120 speakers from 1971.

The SITUATION IN 1971. Three major generalizations emerge regarding the situation in 1971. (i) In 1971, speaker age was a highly determinative factor. Of the 120 speakers, $\mathrm{C} \& \mathrm{C}$ found that among the twenty-five oldest (those age fifty-eight and older in 1971), twenty were categorical users of $[\mathrm{r}]$ and only one had more than $4 \%$ [R]. At the other 
end of the spectrum, many speakers younger than thirty-five in 1971 were categorical or near-categorical users of [R]. (ii) In both trend and panel samples, most speakers tended to be near-categorical users of either INNOvative [R] (with [R] values ranging from $85 \%$ to $100 \%$ ), or of CONSERVATIVE [r] (with [R] values ranging from $0 \%$ to $17 \%$ ). (iii) A minority of speakers exhibited variable behavior, and those variable speakers tended to occupy the $50 \%$ to $80 \%[\mathrm{R}]$ range.

The SITUATION IN 1984. By 1984, a number of important changes had ensued. (i) The real-time evidence from the trend samples shows a massive increase of [R] by 1984. Speakers under twenty-five in 1984 were twenty-five percentage points ahead of their 1971 counterparts in their use of [R], and speakers between age twenty-five and fifty-six in 1984 were forty-one percentage points ahead of their 1971 age mates. (ii) The panel showed a more modest gain. As a group, younger panel speakers increased their use of [R] by fourteen percentage points as compared with their earlier selves; older speakers increased by nine percentage points. In terms of change across the lifespan, panel members divided into three groups whose members behaved differently: (a) Of the twelve majority-[r] speakers of the 1971 panel, ten were stable through 1984, and two moved up dramatically to the mid-range, both registering over $60 \%$ [R] use. (b) All ten speakers who registered $85 \%$ or more [R] in 1971 stayed within that range in 1984. (c) Of the ten mid-range speakers of 1971, seven significantly increased their use of [R], finding themselves in 1984 in the $85 \%$ to $100 \%$ near-categorical range, whereas the three remaining mid-range speakers were stable across the thirteen-year time span. (iii) Among 1984 trend speakers, only one under thirty-five years old used less than $70 \%[\mathrm{R}]$; almost all of these younger speakers were virtually categorical users of $[R]$.

7.2. Resolved AND UnRESOlved Questions. By the evidence reviewed in the preceding section, two possible trajectories can be ruled out as underlying the implementation of this change in the Montreal speech community: (i) the change does NOT proceed mainly by speakers slowly increasing their use of [R] across their lifetimes, and (ii) the change does NOT proceed by successive cohorts of new members entering the speech community bearing a slightly higher value of $[R]$ usage than their older peers. Rather, the inevitable conclusion is that change in the community is a result of individual speakers, especially younger speakers, being added to the pool of majority-users or categorical users of $[\mathrm{R}]$.

What is the process by which new speakers get added to the pool? We saw that both in 1971 and even more in 1984, many speakers in the fifteen-to-nineteen age range were already categorical [R] users when they first entered our study. One important question that we can try to answer on the basis of indirect evidence is: did these young speakers acquire categorical [R] usage as part of their initial language acquisition as young children, or did they join the pool of [R] users sometime between first language acquisition in early childhood and the age of fifteen? Given the fact that almost everyone over the age of thirty-five in 1971 was a categorical user of [r], we would have to assume that input from parents of virtually all children in 1971 was categorical [r]. By 1984, the situation would have changed somewhat. Some adolescents born between 1965 and 1970 would have had parents born after 1945 who themselves were predominant users of [R]. Nevertheless, it seems that the majority of our [R] users whose parents were native Montrealers would have heard the $[\mathrm{r}]$ variant as their primary input in first 
language acquisition. They would thus have differentiated themselves from their parents in later childhood or early adolescence.

Indeed, we have some direct evidence on this point. Almost all of the interviews with adolescents were carried out in the family home. Often a parent was present, and often those parents participated to some extent in the interview, being called on by their sons or daughters, for example, to supply information about where their grandparents came from. In some of these cases, we were fortunate to be able to establish the /r/ pattern of the parent. In sixteen of the thirty-one interviews carried out with young people between fifteen and twenty (including all 1971 and 1984 interviews), parents were present, usually the mother. Although we had much smaller samples of these parents' speech, we found no cases where the parent appeared to be anything but an apical [r] user.

We must conclude that a child with two parents who are categorical users of [r] would have [r] as an initial target form. It follows that in 1971 and to a large extent also in 1984, most people who arrived at age fifteen or sixteen as categorical users of [R] were speakers who had actually switched in childhood or early adolescence. It is possible that in 1971, sixteen-year-old Louis-Pierre R. (092), with 64\% [R], was recorded in the late stages of such a switch, which was complete by 1984, when he had $100 \%$ [R]. This might also be true of some of the other young speakers in Table 12 , given in 1.

(1) Paul D. (064)

Lise L. (071)

Guy T. (088)

Christian B. (025)

$$
\begin{array}{ll}
\text { age } 16-29 & 21 \% \rightarrow 95 \% \\
\text { age } 17-30 & 73 \% \rightarrow 90 \% \\
\text { age } 19-32 & 48 \% \rightarrow 100 \% \\
\text { age } 27-40 & 68 \% \rightarrow 98 \%
\end{array}
$$

The trajectories of these later adopters, whom we were able to observe, might simply be paralleling a similar trajectory made earlier in life by their earlier-adopting peers whose change we did not observe. Indeed it might also be correct to view the two older speakers who registered similar increases as 'very late' adopters: Diane R. (066), age $40-53$, with a $72 \% \rightarrow 97 \%$ increase, and Joseph R. (075), age 53-66, with a $48 \% \rightarrow$ $79 \%$ increase. That a change from virtually categorical $[\mathrm{r}]$ to strongly majority $[\mathrm{R}]$ over a lifetime is possible is shown by the case of Lysiane B. (007), whom we were lucky to be able to follow through 1995. Lysiane went from $7 \%$ to $65 \%$ to $78 \%$ [R] over the twenty-four-year span from 1971 to 1995 (SBC).

The norm is clearly one of relative stability after adolescence, however, as we saw from the fact that a majority of panel members did not change so radically. Our conclusion is that most of those speakers observed to be categorical users of $[R]$ in late adolescence in fact made the switch earlier in life. Although it is possible that some children were influenced by older siblings who had already adopted the innovative form, the fact remains that there is a fairly sharp break between speakers older and younger than thirty-five in the 1971 data. So while it is possible that some younger siblings of early adopters may have acquired the innovation as part of their L1 acquisition, the older siblings themselves must have gone through the switch process.

In considering the source of the innovation and how it spread initially, it is important to look at both geographic and socio/stylistic considerations. C\&C pointed out that among the Montrealers with parents from a traditionally [R]-pronouncing area of Quebec, those over forty showed no particular tendency to be early adopters of [R]; however, they did observe such a tendency for younger speakers. It seems that once the change 
was in progress in Montreal, it was acceptable and even appropriate for younger speakers to retain the pronunciation of their parents in cases where the parents were from $[\mathrm{R}]$-pronouncing regions. ${ }^{12}$

It is clear that we are dealing here with a change from above (the change has a source outside the community; early adopters are more likely to be female and of a higher socioeconomic status). But just how aware are community members of these competing forms of $/ \mathrm{r} /$, and what is their stylistic status? We did not carry out subjective reaction tests at the time when the spontaneous speech was recorded, but there were some speakers who mentioned regional variation in $/ \mathrm{r} /$ pronunciation during the part of the interview when they were questioned about the differences between Montrealers and people from elsewhere. In the excerpt in 2 from a 1971 interview, Denise, the wife of interviewee Alain L. (104) and a Montrealer in her early forties at the time, was the one who brought up / $\mathrm{r}$ / pronunciation when the topic of 'whether you can tell where someone is from by the way they speak' was introduced.

(2) Denise L.: Mes parents moi venaient du Lac St-Jean. Ils grasseyaient.

'My parents came from Lac Saint-Jean. They used to pronounce a "guttural"'/r/.'

Moi-même quand j'ai commencé à aller à l'école puis_-je faisais rire de moi,

'Me too when I started at school and-I got laughed at.' fait-que je me suis dompté. 'Je vas arrêter de rouler les r!' 13

'So I was crushed. 'I'm going to stop rolling my r's!',

Interviewer: Vous avez pris vite l'accent de Montréal?

'Did you pick up the Montreal accent quickly?'

Alain L. Et bien ma femme est née à Montréal,

'Yes well my wife was born in Montreal,'

mais ses parents et les plus vieux de sa famille sont nés au Lac

St-Jean.

'But her parents and the older people in her family were born in Lac Saint-Jean.'

Despite a few remarks of this sort that showed awareness of regional differences, particularly on the part of people who had crossed the east-west $(\mathrm{R} / \mathrm{r})$ line in moving from one area to another, stylistic variation among our 1971 speakers was marginal at best (Sankoff \& Blondeau 2008).

By 1984, the mid-range speakers we examined still did not behave consciously as if the [R] variant held any particular cachet-for most of them, in the upper range of variable usage, it had become the unmarked variant. By contrast, for some younger speakers, [r] seemed to have taken on meanings of being old-fashioned, having the

\footnotetext{
${ }^{12}$ In documenting consonantal changes in the mid-Rhine region of Germany over a thirty-year period, Bellman and colleagues (1999) found a number of changes moving in the direction of Hochdeutsch, but the towns where change was occurring were those that bordered on areas that already had these features. The actual prestige of the Hochdeutsch forms would presumably have been uniform throughout the region, but the effect of prestige was found only on the boundary, that is, with speakers who had contact with those who already used the prestige form. In our sample, Yannick C. (126), a younger speaker (seventeen years old in 1984), was typical of his generation with $100 \%$ [R]. One early influence on his speech, however, may have been the fifteen months he spent with his family in Quebec City at the age of seven when he was in first grade.

${ }^{13}$ Most people contrast grasseyé (dorsal) with roulé (apical), but despite the apparent confusion of these terms on the part of Denise, she clearly means she was under social pressure to stop using the dorsal variant.
} 
ring of one's grandparents, of one's teachers, of the clergy. Some younger speakers used it for comic effect. In 3, Lucie A. (125), age twenty-two in 1984, is talking about the kind of luxurious home she might like to have. She is very serious throughout the passage, using her normal [R] in all of the /r/-words: pouvoir, superbes, pouvoir, rénover, regarde. Then she pulls herself up short from this reverie and the last three lines are very ironic, when she contrasts her true situation with this dream of luxury. In both peut-être and trop, the word is drawn out and the apical [r] clearly signals a comic effect in which she pokes fun at herself for having these visions of another way of life.

(3) Lucie A., age 22 (1984)

... ils étaient bien chanceux de pouvoir [R]

'... they were very lucky to be able'

se payer des loyers comme ça là,

'to pay rents like that,'

puis_-des maisons superbes [R] là. J'aime-

'and the superb homes. I like-'

j' aime ça, la-la la vie qu'il-y-a là-dedans,

'I like that, the - the lifestyle there,'

dans ces maisons là. Ou bien

'in that kind of houses. Or else'

de pouvoir $[R]$ acheter une maison

'to be able to buy a house'

puis de la rénover $[R]$ puis ça, ça-

'and to renovate it, and that, that-'

En tout cas souvent je pense à ça tu-sais

'In any case I often think about that y'know'

puis je regarde $[R]$ moi comment ce-que je vis

'and I look at myself, how I live,'

puis je me dis 'Oui.'

'and I say to myself, "Yeah, right!",

Peut-être [r] un jour! [R]

'Maybe one day!'

Je sais pas trop [r] là.

'I don't really know.'

A further mystery concerns the nature of the allophonic variation both between the two allophones in competition, and between them and the other variants of $/ \mathrm{r} / \mathrm{C} \& \mathrm{C}$, Tousignant 1987a, SBC, Sankoff \& Blondeau 2008). For variable speakers, there is a strong tendency to retain $[\mathrm{r}]$ in onsets, the most salient position, whereas the innovative [R] seems to appear first in codas in which $/ \mathrm{r} /$ is in any case subject to lenition and deletion. It would seem that a high-prestige pronunciation ought to occur first in the most salient position, but in listening to the speech of our variable speakers, it is almost as if $[R]$ creeps in through the back door, where the least attention is being paid. Speakers who tend toward categoriality of either the conservative or the innovative variant tend to have a higher proportion of $[\mathrm{r}]$ and $[\mathrm{R}]$ tokens overall. That is, these speakers have many fewer cases of vocalized or deleted forms than do the intermediate speakers. It is almost as if the intermediate speakers no longer have a clear consonantal target for $/ \mathrm{r} /$. Further details on allophonic conditioning of the other $/ \mathrm{r} /$ variants can be found in Sankoff \& Blondeau 2008. 
The issues of allophonic variation and of stylistic significance may help to shed further light on the implementation of the change, but it is too late to be able to study the situation of L1 acquisition in families where children ended up with a different allophone from that of their parents. Nevertheless, we think that there are two important facts that need to be underlined here: (i) apical [r] must have been the target and the first-acquired form in L1 acquisition for the vast majority of teenagers and young adults in Montreal in 1971 who were early adopters of dorsal [R], given the input they would have had from their parents; and (ii) all of the mid-range speakers under age thirty in 1971 had become categorical or near-categorical users of [R] by 1984. In tracing their trajectories as late adopters, it is reasonable to infer that their early-adopting peers had traced the same trajectory earlier in their lives. Figure 5 sketches the trajectories we envisage for the early adopters, after the pattern of those we observed.

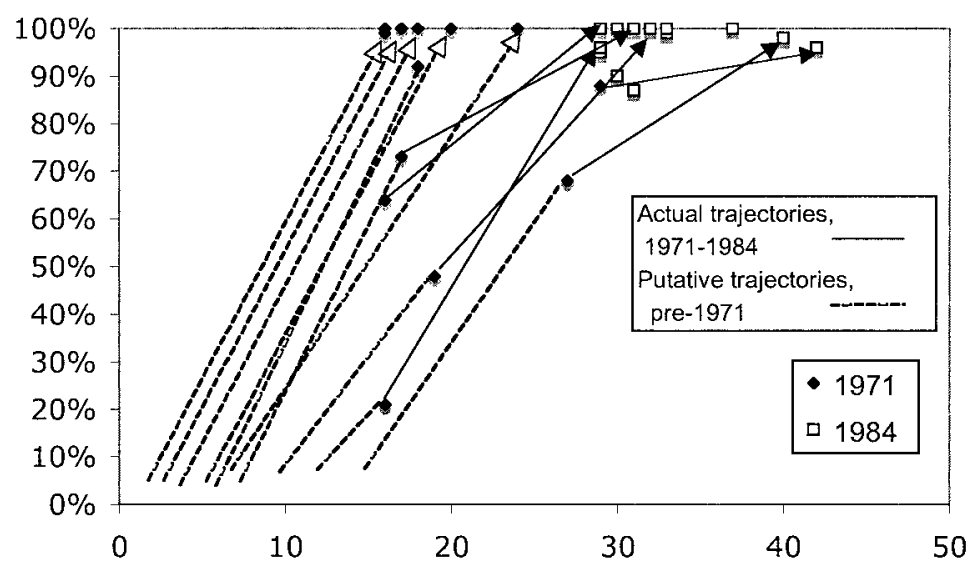

FIGURE 5. Actual trajectories for all mid-range speakers under age 30 in 1971, and putative trajectories for earlier stages.

7.3. Montreal $[\mathrm{r}] \rightarrow[\mathrm{R}]$ In a wider perspective. How do our findings relate to other cases of language change, and to clarifying the relative usefulness of trend and panel studies in longitudinal analysis? Before drawing what we believe to be the general implications of our study for the understanding of change in progress, we must point out two respects in which the case we are dealing with here may differ from that of other changes. We then conclude by stepping back from the current analysis and making some generalizations we believe may be applicable to research in other communities.

The Discrete CHARACTER OF MONTREal / $r$ /. Our findings indicate that this change differs from others described in the literature in one important way: the relative lack of stable variation. More speakers tended to be categorical than variable, and those who changed did so very rapidly.

We noted in $\$ \S 5$ and 6 that (i) most speakers in both 1971 and 1984 were majority users of one of the two variants, rather than occupying the mid portions of the range, and that (ii) panel results revealed variable speakers as tending toward categoriality over time. Such a pattern contrasts markedly with that of most studies of change and variation in vowels, in which gradualism is the order of the day. Gradual changes in frequency have been characteristic of postvocalic / $\mathrm{r}$ / in New York City and New England, where a former $r$-vocalization pattern is now variable, but where change has been slow; age differences among subjects interviewed for the Atlas of North American 
English (Labov et al. 2006) were not significant. There is, however, a striking parallel to the Montreal case in the rapid diffusion of postvocalic /r/ in the American South, where 'r-pronunciation has swept through the region in all styles of speech so that younger white speakers are consistently r-ful' (Labov et al. 2006:47). ${ }^{14}$

Another aspect of our findings that differentiates this change from others that have been studied is that the change in the phonetics of $/ \mathrm{r} /$ does not appear to interact with other aspects of Montreal French phonology. As far as this second point is concerned, we note the conclusion drawn by van Hout and Van de Velde about crosslinguistic variation with respect to /r/: 'Languages may often display almost all of the /r/ sounds commonly mentioned. Transition from one type of $/ \mathrm{r} /$ into another is frequent, not unidirectional, and irrelevant to the linguistic system' (2001:3).

Continuing in this vein, they highlight the observation of Wiese (2001) that for German and other Germanic languages, 'the pattern of /r/ . . shows that the phonotactics is undisturbed by the segmental variations' (van Hout \& Van de Velde 2001:3). Although we do not agree that variation in $/ \mathrm{r} /$ is always without systemic effects (see for example Labov 1966 on vocalic mergers in New York City that are inhibited by $/ \mathrm{r}$ / pronunciation), it seems to be true that in the Montreal French case at least, the change in the phonetics of $[r]$ does not have systemic phonological consequences. Beginning with Labov 1963, many studies that have used the apparent-time construct as an indicator of change in progress have been studies of vowels and vowel systems; change is often systemic, with chain shifts and parallel shifts more common than isolated, individual changes. It would seem that the more embedded any given change is as part of a structural system, the less susceptible it might be to individual initiative of the sort we saw on the part of speakers like Lysiane B. Preliminary work on the diphthongization of the mid vowels /o/ (as in chose) and /eu/ (as in beurre) across individual lifespans in Montreal (Sankoff et al. 2006) has shown a smaller degree of change than is the case with $/ \mathrm{r} / .^{15}$

The IMPlications of MONTREAL $[\mathrm{r}] \rightarrow[\mathrm{R}]$. Our study has three major implications that are relevant for other research on change in progress, and for the relationship of change in the community to change across individual lifespans.

(i) Trend vs. panel comparisons in the assessment of change in progress. Our study has provided clear evidence for an important methodological principle in longitudinal research: in order to verify inferences about apparent time drawn from synchronic studies, the most important tool is a carefully designed trend study. We saw that the increases made by panel-study members were only a pale reflection of what was going on in the wider community. In using [R] more frequently, older speakers are by no means leading the change, although some are behaving somewhat like younger members of the community.

\footnotetext{
${ }^{14}$ This rapid change, inferred from a coefficient of -14 (probability $<0.0001$ ) for an age difference of twenty-five years (Labov et al. 2006:48), means that a speaker age twenty-five with $100 \%$ postvocalic/r/ might have a grandparent age seventy-five who had only $72 \%$.

${ }^{15}$ In longitudinal research on Montreal French mid vowels and on the back /a/ in -ation words, Kemp and Yaeger-Dror (1991), Yaeger-Dror and Kemp (1992), and Yaeger-Dror (1989, 1994, 1996) have traced developments in real time through the use of early-twentieth-century radio broadcasts as compared with similar recordings from the same speakers twenty to forty years later. They also used data from the 1971 and 1984 Montreal corpora. Summarizing the results of panel comparisons involving eight speakers recorded in 1971 and 1984, Yaeger-Dror states that speakers may continue 'to advance their [vowel phonology] toward a newer phonology well into middle age' (1994:284-86).
} 
(ii) Implications for the use of the apparent-time construct. In several studies of longitudinal change reviewed in Labov 1994 (New York City, Panama, Norwich), the results were similar to those presented here in that the age distribution at time B was analyzable in terms both of community change since time A and of the component referred to by Labov as age grading. Although the results reviewed by Labov were based on trend, not panel, studies, this second component clearly has to do with change over the lifespan. Labov's conclusion comparing the restudies of New York City and Panama City presages the results we found:

\begin{abstract}
In each case, age-grading is the dominant configuration. In succeeding generations, speakers follow the same pattern across apparent time. But there is also a steady increment of the process at a lower level, showing that a real-time change is taking place. This suggests that in trying to decide which model is correct for a given process, we may have been setting up a misleading opposition between age-grading and generational change. It is possible that age-grading is involved in the mechanism of real-time change for certain types of linguistic change. (Labov 1994:97)
\end{abstract}

Our findings, along with this reasoned opinion of Labov's, motivate our proposal to add a new category labeled LIFESPAN CHANGE (as proposed in Table 2) to the model of the relationship between generational change and age grading. This concept differs from age grading (which generally involves cyclicity), as discussed in $§ 1$.

In our research reported here, the trend study was invaluable in establishing both the direction and the rate of change. However, in most cases where we are interested in assessing change in progress, we do not have the luxury of a trend study. In such cases, we want to know how much we can rely on apparent-time inferences. Here the findings of the panel study must be considered. Insofar as the movement among panel speakers was decidedly directional, with some older speakers going along with the change, there is an important conclusion to be drawn about apparent-time inferencing. If a significant minority of older speakers has actually gone along with the change in adult life, then means derived from a cohort of older speakers actually overestimate their rates of use of the variable as children. In an apparent-time calculation, we would normally assume that if, for example, speakers age forty-five to fifty are using the innovative variant at a rate of $50 \%$, whereas fifteen-to-twenty year olds are using it at a rate of $80 \%$, then there has been an increase of thirty percentage points over the thirty-year period, an average of ten percentage points per decade. But if indeed that cohort of forty-five-to-fifty year olds have themselves inched up ten percentage points as a group since their teens, then the true value of that cohort thirty years earlier would not have been $50 \%$ (the rate they show today), but only $40 \%$. The conclusion is inescapable: to the extent that older speakers change in the direction of change in progress in their adult lives, apparent time unDERESTIMATES the rate of change. A major implication of our study for other research that relies on inferences from systematic synchronic-age distributions is that apparent-time calculations correctly identify the direction of change, but may underestimate the rate of change, a conclusion also reached by Boberg (2004) in a study of Montreal English. ${ }^{16}$

\footnotetext{
${ }^{16}$ According to Boberg, "the behavior of older speakers in late adoption contributes to the speed with which an innovative feature replaces an obsolescent feature in the community as a whole. In this sense, late adoption accelerates rather than retards changes in progress' (2004:258). Contrasting the two phonological variables he studied with numerous lexical variables, Boberg's judicious assessment was that late acquisition by adults was 'most characteristic of lexical variation' (ibid, p. 250), rather than phonological variation as we have seen here.
} 
We concur with Bailey et al. 1991, Bailey 2002, and Tillery \& Bailey 2003 that earlier worries about the validity of apparent time in identifying change in progress have proven to be exaggerated.

(iii) Implications for the relevance of the critical period to language change. Expecting relative stability in later life, we were surprised to see such a substantial minority of speakers making major changes in their pronunciation. Of the twenty-two speakers who might have changed, nine (about 40\%) did so. The most stable group was the categorical and near-categorical users of [r]: only two of the twelve departed from this initial pattern. Seven of the ten mid-range speakers increased significantly, however, moving to the categorical/near-categorical range of use of dorsal $[R]$. They included all of those speakers under age thirty in the original study. This and other evidence led us to conclude that most of the majority users of [R] in the 1970s and 1980s had changed their pronunciation at some time later than the period of initial L1 acquisition.

This evidence should not be interpreted as a blow against the reality of the critical period, but as an indication of the necessity for greater attention to be focused on the degree and kind of lability that occurs in later life. Relative stability of individual speakers in panel studies has been documented by Brink and Lund (1975), Labov and Auger (1998), and Nahkola and Saanilahti (2004). By contrast, Kemp and Yaeger-Dror (1991), Baugh (1995), Naro and Scherre (2002), and Zilles (2005) have shown that some individuals have made significant changes in later life. Guy and Boyd (1990) presented a cogent scenario of how English speakers deepen their knowledge of the morphology of tense marking across their lifespans: in the 'semiweak' verb class (kept, told), children's final $t / d$ deletion patterns with that for monomorphemes; adults, however, apparently deepen their analysis and treat the $t / d$ of semiweak verbs like past tense morphemes. And whereas comprehension of second-dialect features has been shown to increase in adult life (Sankoff 1980), production of second-dialect features is a piecemeal affair for both adolescents and adults, generally lacking the systematic character of first language acquisition and subject to considerable interspeaker variability (Chambers 1992, Bowie 2000, Kerswill \& Williams 2000, Sankoff 2004). Meyerhoff and Walker (2007) have demonstrated that long-term 'urban sojourners' from the Caribbean island of Bequia have retained native grammatical constraints on copula variation despite considerable exposure to other dialects as adults. It is likely that the adoption of changes characteristic of younger speakers in one's own community has many commonalities with this process.

Our results require us to rethink the relationship between L1 and later language acquisition, and between acquisition and change. Are late-adopting young adults simply an epiphenomenon with respect to community change, following along behind the younger leaders? Or do they have any influence on the children growing up after them? In the case of a change from above like this one, the model of child innovators with no adult input seems unlikely. ${ }^{17}$ Certainly the fact that adults use dorsal $[\mathrm{R}]$ at higher frequencies contributes to the overall input from the community that children hear as they form their phonological systems. Hay and colleagues (2006) show that in a change in progress (the fear/fare merger in New Zealand), community members have quite accurate perceptions of generational and social-class differences between speakers who

\footnotetext{
${ }^{17}$ Such a scenario, with child innovators in the lead and adults trailing behind, seems clearly the correct one in a case like the change from below involving the spread of the new verb of quotation, be like (CukorAvila 2002, Tagliamonte \& D’Arcy 2005).
} 
do and do not produce the merger, and use this knowledge in differentially decoding the same acoustic signal. And in a study of caregivers' speech to children in a Scottish community where a local phonetic variant of the diphthong (au) is in variation with a standard variant, Smith and colleagues (2007) have shown that caregivers who use the local variant almost exclusively in their general spontaneous speech nevertheless use the standard at very high rates to young children, especially in contexts of teaching and discipline.

(4) It's r[u:]nd the wrong way, no turn it $r[\Lambda \mathrm{t}]$ nd!

(Caregiver to child in Buckie, Scotland; from Smith et al. 2007:70)

The youngest children replicate these very high rates, whereas slightly older children use more of the local variant. Clearly the (au) variable is highly salient in Buckie, in contrast to the situation of $/ \mathrm{r} /$ in Montreal; however, this study points to social differentiation in usage patterns during L1 acquisition of a type that may well have an impact on language change.

A further question involves how to model what is going on for speakers who show a dramatic range in their trajectories over only thirteen years. Should we view these people as having restructured their phonologies? Adjustment in the frequencies of two variants speakers already possessed from childhood seems perhaps like a relatively minor change. But several people replaced the unmarked, vernacular $[\mathrm{r}]$ that they appeared to use spontaneously and unreflectingly with the innovative [R] characteristic of speakers younger than themselves. As we demonstrate elsewhere (Sankoff \& Blondeau 2008), these speakers have also altered their constraint hierarchies: majority users of [R] seem to retain [r] only in onsets, which was not characteristic of their earlier phonological systems as inferrable from their speech production. Pace Anderson and Lightfoot (2002), our results lead us to believe that adults' abstract phonological systems at age thirty, or forty, or fifty are different from what they were in childhood or at puberty. ${ }^{18}$ Change is dramatic in childhood, but it does not stop there. To understand the dynamics of change in the speech community, we must follow language across the lifespan.

\section{REFERENCES}

Anderson, Stephen, and David Lightfoot. 2002. The language organ: Linguistics as cognitive physiology. Cambridge: Cambridge University Press.

Ashby, William J. 2001. Un nouveau regard sur la chute du ne en français parlé tourangeau: S'agit-il d'un changement en cours? French Language Studies 11.1-22.

BAILEY, Guy. 2002. Real and apparent time. The handbook of language variation and change, ed. by Jack K. Chambers, Peter Trudgill, and Natalie Schilling-Estes, 312-32. Oxford: Blackwell.

Bailey, Guy; Tom Wikle; JAN Tillery; and Lori SAND. 1991. The apparent time construct. Language Variation and Change 3.241-64.

BAUgh, John. 1995. Dimensions of a theory of econolinguistics. Towards a social science of language: Papers in honor of William Labov. Vol. 1: Variation and change in language and society, ed. by Gregory R. Guy, Crawford Feagin, Deborah Schiffrin, and John Baugh, 397-419. Amsterdam: John Benjamins.

Bellmann, Günter; Joachim Herrgen; and Jürgen Erich Schmidt. 1999. Mittelrheinischer Sprachatlas, Band 4: Konsonantismus (Dialektalität. Konsonanten des westgermanischen Bezugssystems. Sproßkonsonanten). Tübingen: Niemeyer.

Blake Renee, and Meredith Josey. 2003. The /ay/ diphthong in a Martha's Vineyard community: What can we say 40 years after Labov? Language in Society 32.451-85.

${ }^{18}$ Adult phonology is probably also influenced by literacy. See for example Labov 1964 and Treiman et al. 2002. 
BlondeAu, Hélène. 2001. Real-time changes in the paradigm of personal pronouns in Montreal French. Journal of Sociolinguistics 5.453-74.

BlondeAu, HÉLÈne. 2006. Panel studies and language variation. Encyclopedia of languages and linguistics, 2nd edn., vol. 9, ed. by Keith Brown, 150-54. Oxford: Elsevier.

Blondeau, Hélène; Gillian Sankoff; and Anne Charity. 2002. Parcours individuels et changements linguistiques en cours dans la communauté francophone montréalaise. Revue québécoise de linguistique 31.13-38.

Boberg, Charles. 2004. Real and apparent time in language change: Late adoption of changes in Montreal English. American Speech 79.250-69.

BowIE, DAVID. 2000. The effect of geographic mobility on the retention of a local dialect. Philadelphia: University of Pennsylvania dissertation.

BRINK, LARS, and J $\phi$ RN Lund. 1975. Dansk Rigsmål I-II: Lydudviklingen siden 1840 med særligt henblink på sociolekterne i København. [Standard Danish I-II: The phonetic development since 1840 with special regard to the sociolects in Copenhagen.] Copenhagen: Gyldendal.

BRINK, LARS, and J $\phi$ RN LUND. 1979. Social factors in the sound changes of modern Danish. Proceedings of the ninth International Congress of Phonetic Sciences, vol. 2, 196-203. Copenhagen: University of Copenhagen.

Cedergren, Henrietta. 1988. The spread of language change: Verifying inferences of linguistic diffusion. Language spread and language policy: Issues, implications, and case studies (Georgetown University Round Table on Languages and Linguistics 1987), ed. by Peter H. Lowenberg, 45-60. Washington, DC: Georgetown University Press.

Chambers, JACK K. 1992. Dialect acquisition. Language 68.673-706.

Charbonneau, RenÉ. 1955. Recherches d'une norme phonétique dans la région de Montréal. Études sur le parler français au Canada, 83-98. Sainte-Foy, QC: Presses de l'Université Laval.

Clermont, Jean, and Henrietta Cedergren. 1979. Les 'R' de ma mere sont perdus dans l'air. Le français parlé: Etudes sociolinguistiques, ed. by Pierrette Thibault, 13-28. Edmonton, AB: Linguistic Research.

Cukor-Avila, Patricia. 2002. She say, she go, she be like: Verbs of quotation over time in African American Vernacular English. American Speech 77.3-31.

de Paiva, Maria, and Maria Eugenia Duarte. 2003. Mudança lingüística em tempo real. Rio de Janeiro: Capa.

Guy, Gregory, and SAlly Boyd. 1990. The development of a morphological class. Language Variation and Change 2.1-18.

Hay, Jennifer; Paul Warren; and Katie Drager. 2006. Factors influencing speech perception in the context of a merger-in-progress. Journal of Phonetics 34.458-84.

Hernandez-Campoy, Juan Manuel. 2003. Complementary approaches to the diffusion of standard features in a local community. Social dialectology: In honour of Peter Trudgill, ed. by David Britain and Jenny Cheshire, 23-37. Amsterdam: John Benjamins.

Hubbell, Allan Forbes. 1950. The pronunciation of English in New York City: Consonants and vowels. New York: King's Crown Press.

Josey, Meredith. 2004. A sociolinguistic study of phonetic variation and change on the island of Martha's Vineyard. New York: New York University dissertation.

Kemp, William, and Malcah YaEger-Dror. 1991. Changing realizations of A in (a)tion in relation to the front A-back A opposition in Quebec French. New ways of analyzing sound change, ed. by Penelope Eckert, 127-84. New York: Academic Press.

Kerswill, Paul, and Ann Williams. 2000. Creating a new town koine: Children and language change in Milton Keynes. Language in Society 29.65-115.

Labov, William. 1963. The social motivation of a sound change. Word 19.273-309. [Revised as Ch. 1 in Sociolinguistic patterns. Philadelphia: University of Pennsylvania Press, 1973.]

Labov, William. 1964. Stages in the acquisition of standard English. Social dialects and language learning, ed. by Roger Shuy, 77-103. Champaign, IL: National Council of Teachers of English. [Reprinted in Readings in Amerian dialectology, ed. by 
H. B. Allen and Gary Underwood, 473-98. New York: Appleton-Century-Crofts, 1971].

Labov, WiLliam. 1966. The social stratification of English in New York City. Washington, DC: Center for Applied Linguistics. [2nd edn., Cambridge: Cambridge University Press, 2006.]

Labov, William. 1975. On the use of the present to explain the past. Proceedings of the 11th International Congress of Linguists, ed. by Luigi Heilmann, 825-51. Bologna: Il Mulino. [Reprinted in Linguistics at the crossroads, ed. by Adam Makkai, Valerie Becker Makkai, and Luigi Heilmann, 226-61. Padova: Liviana, 1977.]

Labov, William. 1994. Principles of linguistic change, vol. 1: Internal factors. Oxford: Blackwell.

Labov, William; Sharon Ash; and Charles Boberg. 2006. Atlas of North American English. Berlin: Mouton de Gruyter.

Labov, William, and Julie Auger. 1998. The effect of normal aging on discourse: A sociolinguistic approach. Narrative discourse in neurologically impaired and normal aging adults, ed. by Hiram Brownell and Yves Joanette, 115-34. San Diego, CA: Singular.

Lightfoot, DAvid W. 1999. The development of language: Acquisition, change, and evolution. Oxford: Blackwell.

Meyerhoff, Miriam, and James A. Walker. 2007. The persistence of variation in individual grammars: Copula absence in 'urban sojourners' and their stay-at-home peers, Bequia (St Vincent and the Grenadines). Journal of Sociolinguistics 11.346-66.

Morin, Yves-Charles. 2002. Les premiers immigrants et la prononciation du français au Québec. Revue québécoise de linguistique 31.39-78.

NahKola, Kari, and Maria SaAnilahti. 2004. Mapping language changes in real time: A panel study on Finnish. Language Variation and Change 16.75-92.

Naro, Anthony, and Maria Marta Pereira Scherre. 2002. The individual and the community in real-time linguistic change: Social dimensions. Paper presented at New Ways of Analyzing Variation (NWAV) 31, Stanford, CA, October 13.

PAunonen, HeikKi. 1996. Language change in apparent time and in real time. Samspel \& Variation: Sprakliga studier tillägnade Bengt Nordberg pa 60-arsdagen, 375-86. Uppsala: Uppsala Universitet, Institut för Nordiska Sprak.

Rivard, AdJutor. 1928 [1901]. Manuel de la parole. 2nd edn. Quebec: Garneau.

Sankoff, David, and Suzanne Laberge. 1978. The linguistic market and the statistical explanation of variability. Linguistic variation: Models and methods, ed. by David Sankoff, 239-50. New York: Academic Press.

Sankoff, David, and Gillian Sankoff. 1973. Sample survey methods and computerassisted analysis in the study of grammatical variation. Canadian languages in their social context, ed. by Regna Darnell, 7-64. Edmonton, AB: Linguistic Research.

SAnKofF, Gillian. 1980. Mutual intelligibility, bilingualism and linguistic boundaries. The social life of language, by Gillian Sankoff, 133-41. Philadelphia: University of Pennsylvania Press.

SANKOFF, Gillian. 2004. Adolescents, young adults and the critical period: Two case studies from 'Seven Up'. Sociolinguistic variation: Critical reflections, ed. by Carmen Fought, 121-39. Oxford: Oxford University Press.

SankofF, Gillian. 2005. Cross-sectional and longitudinal studies in sociolinguistics. An international handbook of the science of language and society, vol. 2, ed. by Ulrich Ammon, Norbert Dittmar, Klaus J. Mattheier, and Peter Trudgill, 1003-13. Berlin: Mouton de Gruyter.

Sankoff, Gillian. 2006. Age: Apparent time and real time. The encyclopedia of language and linguistics, 2nd edn., vol. 1, ed. by Keith Brown, 110-16. Oxford: Elsevier.

Sankoff, Gillian, and Hélène Blondeau. 2008. Instability of the $[\mathrm{r}] \sim[\mathrm{R}]$ alternation in Montreal French: The conditioning of a sound change in progress. ' $r$-atics 2 (Special issue of Études \& Travaux), ed. by Hans Van de Velde and Roeland van Hout, to appear.

Sankoff, Gillian; Hélène Blondeau; and Anne Charity. 2001. Individual roles in a realtime change: Montreal $(\mathrm{r} \rightarrow \mathrm{R})$ 1947-1995. In Van de Velde \& van Hout, 141-57. 
Sankoff, Gillian; Michael Friesner; Damien Hall; and Hélène Blondeau. 2006. Le facteur temps et le changement phonétique dans le français montréalais. Paper presented at Les français d'ici, Queen's University, Kingston, ON, June 5.

Santerre, Laurent. 1978. Les /R/ montréalais en régression rapide. Protée 2.117-30.

Smith, Jennifer; Mercedes Durham; and Liane Fortune. 2007. 'Mam, my trousers is fa'in doon!': Community, caregiver, and child in the acquisition of variation in a Scottish dialect. Language Variation and Change 19.63-99.

Tagliamonte, Sali, and Alex D'Arcy. 2005. He's like, she's like: The quotative system in Canadian youth. Journal of Sociolinguistics 8.493-514.

Thibault, Pierrette, and Michelle Daveluy. 1989. Quelques traces du passage du temps dans le parler des Montréalais, 1971-1984. Language Variation and Change 1.19-45.

Thibault, Pierrette, and Diane Vincent. 1990. Un corpus de français parlé. Montréal 84: Historique, méthodes et perspectives de recherche. Sainte-Foy, QC: Département de langues et linguistique, Université Laval.

Tillery, JAN, and GuY Bailey. 2003. Approaches to real time in dialectology and sociolinguistics. World Englishes 22.351-65.

Tousignant, Claude. 1987a. La variation sociolinguistique: Modèle québécois et méthode d'analyse. Montreal: Presses de l'Université du Québec.

Tousignant, Claude. 1987b. Relations sociales entre le /r/ vélaire et le /r/ rétroflexe anglais de Montréal. Revue québécoise de linguistique théorique et appliquée 6.39-55.

Tousignant, Claude. 1987c. Les variantes du /R/ montréalais: Contextes phonologiques favorisant leur apparition. Revue québécoise de linguistique théorique et appliquée $6.73-113$.

Treiman, Rebecca; Judy Bowey; and Derrick Bourassa. 2002. Segmentation of spoken words into syllables by English-speaking children as compared to adults. Journal of Experimental Child Psychology 83.213-38.

Trudgill, Peter. 1988. Norwich revisited: Recent linguistic changes in an English urban dialect. English World Wide 9.33-49.

Van de Velde, Hans, and Roeland van Hout (eds.) 2001. 'r-atics: Sociolinguistic, phonetic and phonological characteristics of $|r|$ (Special issue of Études \& Travaux 4).

van Hout, Roeland, and Hans Van de Velde. 2001. Patterns of /r/ variation. In Van de Velde \& van Hout, 1-9.

Verreault, Claude, and Thomas Lavoie. 1999. 'La langue de nos gens' du père Laurent Tremblay: Une première synthèse sur la variation géolinguistique du français parlé au Québec au début des années 1940. Langues et Linguistique 25.145-212.

Vinay, Jean-Paul. 1950. Bout de la langue ou fond de la gorge? French Review 23.489-98.

Vincent, Diane; Marty Laforest; and Guylaine Martel. 1995. Le corpus de Montréal 1995: Adaptation de la méthode d'enquête sociolinguistique pour l'analyse conversationnelle. Dialangue 6.29-46.

Weinreich, Uriel; William Labov; and Marvin Herzog. 1968. Empirical foundations for a theory of language change. Directions for historical linguistics, ed. by Winfred Lehmann and Yakov Malkiel, 97-195. Austin: University of Texas Press.

Wiese, Richard. 2001. The unity and variation of (German)/r/. In Van de Velde \& Van Hout, 11-26.

Yaeger-Dror, Malcah. 1989. Real time vs. apparent time change in Montreal French. York Papers in Linguistics 13.141-53.

Yaeger-Dror, Malcah. 1994. Sound change in Montreal French. Phonological structure and phonetic form: Papers in laboratory phonology 3, ed. by Patricia Keating, 267-92. Cambridge: Cambridge University Press.

YAeger-Dror, Malcah. 1996. Phonetic evidence for the evolution of lexical classes: The case of a Montreal French vowel shift. Towards a social science of language: Papers in honor of William Labov. Vol. 2: The linguistic structure of variation and change, ed. by Gregory R. Guy, Crawford Feagin, John Baugh, and Deborah Schiffrin, 263-87. Amsterdam: John Benjamins.

Yaeger-Dror, Malcah, and William Kemp. 1992. Lexical classes in Montreal French: The case of (ع:). Language and Speech 35.251-93. 
Zilles, Ana Maria S. 2005. The development of a new pronoun: The linguistic and social embedding of a gente in Brazilian Portuguese. Language Variation and Change 17.19-53.

\section{Sankoff}

Department of Linguistics

University of Pennsylvania

619 Williams Hall

Philadelphia, PA 19104-6305

[gsankoff@earthlink.net]

Blondeau

Department of Romance Languages and Literatures

University of Florida

170 Dauer Hall

P.O. Box 117405

Gainesville, FL 32611-7405

[blondeau@ufl.edu]
[Received 10 August 2006; accepted 8 February 2007] 